\title{
Przekształcenia w powszechnym wymiarze sprawiedliwości w Polsce w latach 1944-1956
}

I. Problematyka związana z przekształceniami w powszechnym wymiarze sprawiedliwości w Polsce w latach 1944-1956 była już przedmiotem badań naukowych po 1989 r. ${ }^{1}$ Jednak w dalszym ciągu zasięg zainteresowania tym problemem jest duży. W niniejszym tekście pragnę przedstawić te zagadnienia w oparciu o nowe materiały źródłowe, które pogłębiają naszą wiedzę na ten temat, jak również prowadzą do poznania losów zawodowych przedstawicieli wymiaru sprawiedliwości. Celem szkicu jest ukazanie tylko tych regulacji prawnych, które dotyczyły sprawności procedury sądowej, jej kierunku i mechanizmu działania i miały zasadnicze znaczenie dla realizacji zadań, jakie nowa władza postawiła przed wymiarem sprawiedliwości w Polsce w latach 1944-1956.

II. Po zakończeniu działań wojennych powszechny wymiar sprawiedliwości funkcjonował na zasadach prawnych przyjętych w okresie międzywojen-

1 Wśród szczególnie wartościowych rozpraw poświęconych tym zagadnieniom należy wskazać prace Adama Lityńskiego, szczególnie Historia prawa Polski Ludowej. Wyd. 5, Warszawa 2013. Zob. także, A. Rzepliński, Sądownictwo w PRL, Warszawa 1990. Komunistycznym prawem Polski Ludowej, gdzie granica badań ustalona została na 1956 r., zajmowali się: A. StawarskaRippel, Prawo sadowe Polski Ludowej 1944-1950 a prawo Drugiej Rzeczypospolitej, Katowice 2006; G. Jakubowski, Sadownictwo powszechne w Polsce w latach 1944-1950, Warszawa 2002; P. Kładoczny, Prawo jako narzędzie represji w Polsce Ludowej (1944-1956), Warszawa 2004; Z.A. Ziemba, Prawo przeciwko spoleczeństwu. Polskie prawo karne w latach 1944-1956, Warszawa 1997. Niektóre aspekty prawa Polski Ludowej, a w szczególności te, które stały się podstawą funkcjonowania wojskowego wymiaru sprawiedliwości opisali: K. Szwagrzyk, Prawnicy czasu bezprawia. Sędziowie i prokuratorzy wojskowi w Polsce 1944-1956, Kraków-Wrocław 2005, s. 33-61; E. Romanowska, Karzace ramię sprawiedliwości ludowej. Prokuratury wojskowe w Polsce w latach 1944-1955, Warszawa 2012, s. 31-133; J. Żelazko, „Ludowa sprawiedliwość”. Skazani przez Wojskowy Sąd Rejonowy w Łodzi (1946-1955), Łódź 2007, s. 92-125; F. Musiał, Polityka czy sprawiedliwość? Wojskowy Sąd Rejonowy w Krakowie (1946-1955), Kraków 2005, s. 23-35; R. Ptaszyński, Wojskowy Są Rejonowy i Wojskowa Prokuratura Rejonowa w Szczecinie w latach 1946-1955, Szczecin 2010. 
nym. W myśl tych zasad w zakresie prawa karnego materialnego obowiązywał kodeks karny z 1932 r. ${ }^{2}$, zwany powszechnie ,kodeksem Makarewicza”, a w zakresie prawa procesowego kodeks postępowania karnego z $1928 \mathrm{r}^{3}$. Akty te oparte były na postępowych projektach ówczesnej Komisji Kodyfikacyjnej. Tworzone były z dużą kulturą oraz poczuciem demokracji i humanitaryzmu. Jednak z uwagi na ,polityczne potrzeby” unormowania te zostały uznane przez kierownictwo partyjne i polityczne w powojennej Polsce za niedostateczny instrument walki z przeciwnikami nowej władzy. Postanowiono dokonać zmian w prawie karnym materialnym i procesowym w taki sposób, aby ograniczyć właściwość sądów i prokuratur powszechnych w wielu kategoriach przestępstw uznanych za polityczne. W celu realizacji tego zamierzenia zaczęto tworzyć system, określany początkowo jako przejściowy, wzorowany na systemie organizacyjnym i dorobku sowieckich organów wymiaru sprawiedliwości. Dominującą rolę w tym systemie odgrywać miała prokuratura wyposażona w szczególne kompetencje oraz Urząd Bezpieczeństwa Publicznego i Informacja Wojskowa.

W państwach demokratycznych celem prawa karnego jest ochrona podstawowych wartości cennych dla obywateli, państwa i narodu, rozumianych jako dobro wspólne tworzących go ludzi. Niestety w Polsce stalinowskiej prawo karne straciło ten przymiot i było często wykorzystywane do walki z człowiekiem. W badanym okresie sądom i prokuraturze wyznaczono zadania ,walki z wszelkimi zamachami na interesy społeczne, gospodarcze i polityczne ludowego państwa”. Skuteczność tej walki w głównej mierze zależała od sprawności procedury sądowej, od jej kierunku i mechanizmu działania ${ }^{4}$.

Wśród licznych dekretów zawierających przepisy karne podstawowe znaczenie miał dekret z 31 sierpnia 1944 r. o wymiarze kary dla faszystowsko-hitlerowskich zbrodniarzy winnych zabójstw i znęcania się nad ludnościa i jeńcami oraz dla zdrajców narodu polskiego, dla którego pierwowzór stanowiły unormowania zapożyczone $\mathrm{z}$ sowieckiego ustawodawstwa ${ }^{5}$. Z dekretem tym łączył się kolejny z 12 września 1944 r. ${ }^{6}$ o specjalnych sądach karnych dla spraw zbrodniarzy faszystowsko-hitlerowskich.

2 Dz. U. 1932, Nr 60, poz. 571.

3 Dz. U. 1928, Nr 33, poz. 313.

4 Archiwum Akt Nowych (AAN), Komitet Centralny Polskiej Zjednoczonej Partii Robotniczej (KC PZPR), VII/2, Protokoły posiedzeń Sekretariatu KC z załącznikami, k. 63.

5 Pierwowzór stanowił dekret z 30 V 1944 r., który miał ten sam tytuł, co Dekret Prezydium Rady Najwyższej ZSRR z 19 IV 1943 r. o wymiarze kary dla niemiecko-faszystowskich zbrodniarzy winnych zabójstw i znęcania się nad radziecka ludnościa cywilna i jeńcami wojennymi - żotnierzami Armii Czerwonej, dla szpiegówi zdrajców Ojczyzny spośród obywateli radzieckich i ich popleczników. Por. J. Wojciechowska, Zdrada ojczyzny w polskim prawie karnym na tle porównawczym, Wrocław-Warszawa-Kraków-Gdańsk 1975, s. 41. Dekret ten nie znalazł jednak zastosowania w praktyce sądowej z uwagi na bardzo krótki okres obowiązywania.

6 Dz.U. 1944, Nr 4, poz. 21. 
W dekrecie z 31 sierpnia 1944 r. po raz pierwszy w historii polskiego prawa karnego odebrano sędziom kompetencje do „wymierzania” kary. W artykule 1 cytowanego dekretu kara śmierci określona była bowiem w sposób absolutny, tj. w sposób wykluczający każdą inną karę jako alternatywną wobec kary śmierci. Karalne były: udział w zabójstwie osób cywilnych i jeńców, znęcanie się nad nimi lub ich prześladowanie, udział w ujęciu osób poszukiwanych przez władze okupacyjne oraz inne działania na szkodę osób przebywających na obszarze państwa. Surowej ocenie podlegały wszystkie działania na szkodę państwa polskiego, polskiej osoby prawnej. Karano donosicielstwo do władz okupacyjnych i inne formy współpracy z nimi. Zatem w przypadku ustalenia, że winowajca popełnił czyn określony w dekrecie, sędzia musiał skazać go na karę śmierci, nawet jeśli ustalił, że w konkretnym rozpatrywanym zdarzeniu zaistniały okoliczności łagodzące czy wręcz usprawiedliwiające zachowanie człowieka, np. jeśli czyn ten popełnił pod przymusem.

Dekret sierpniowy był wielokrotnie nowelizowany. W wyniku przeprowadzonych zmian złagodzono niektóre zapisy (zwłaszcza dotyczące wyłączenia spod bezwzględnie określonej sankcji w postaci kary śmierci niektórych rodzajów działań) i wprowadzono postanowienia wynikające z orzecznictwa Międzynarodowego Trybunału Wojskowego w Norymberdze. Zgromadzenie Ogólne Organizacji Narodów Zjednoczonych w rezolucji z grudnia 1946 r. uznało tzw. zasady norymberskie (Statut MTW, wyrok procesu w sprawie głównych zbrodniarzy wojennych z 1 października $1946 \mathrm{r}$. i wyroki procesów pochodnych) za podstawę kształtowania prawa międzynarodowego w sprawie ścigania przestępców wojennych. W czasie procesu w Norymberdze uznano NSDAP, SS, SD i Gestapo za organizacje przestępcze, co umożliwiło szerokie zastosowanie tego orzecznictwa $\mathrm{w}$ działalności polskiego wymiaru sprawiedliwości. 10 grudnia 1946 r. ukazał się jednolity tekst „dekretu sierpniowego" "T. Wprowadzono zasadę, że dekret stosuje się również wobec osób podlegających sądownictwu wojskowemu.

Należy pamiętać, że dekret sierpniowy w swej pierwotnej postaci ustanawiał odpowiedzialność karną wobec osób winnych dokonania zbrodni wojennych w Polsce, których rozmiar był ogromny. Sprawy dotyczące przestępstw wojennych stanowiły jeden z najważniejszych i przyciągających powszechną uwagę problemów. Już w czasie drugiej wojny światowej ukształtowało się stanowisko, że rzeczą konieczną jest ustanowienie międzynarodowej odpowiedzialności karnej osób winnych przestępstw i zbrodni wojennych. Jednym z pierwszych dokumentów dotyczących tej kwestii była Deklaracja z St. James Palace, przyjęta 13 stycznia 1942 r. przez emigracyjne rządy państw pozostających pod okupacją państw Osi. Deklaracja moskiewska o okrucieństwach,

\footnotetext{
7 Dz. U. 1946, Nr 69, poz. 376.
} 
przyjęta 1 listopada 1943 r. przez Wielką Brytanię, USA i ZSRS na konferencji w Moskwie, zapowiadała ukaranie na mocy prawa międzynarodowego hitlerowskich zbrodniarzy wojennych ${ }^{8}$.

Ukaranie przestępców, zdrajców i zbrodniarzy niemieckich przewidywały również władze polskie. 30 marca 1943 r. został wydany dekret Prezydenta Rzeczypospolitej Polskiej o odpowiedzialności karnej za zbrodnie wojenne ${ }^{9}$, przewidujący stosowanie surowych kar wobec winnych zbrodni i przestępstw. W okresie okupacji zorganizowano sprawnie działający wymiar sprawiedliwości Polskiego Państwa Podziemnego, który miał zająć się sądzeniem agentów, konfidentów i bandytów ${ }^{10}$. Po zdobyciu władzy komuniści rozpoczęli działania zmierzające do tego, aby winni dokonania zbrodni wojennych zostali ukarani. Już w Manifeście Lipcowym Krajowa Rada Narodowa zapowiadała szybkie i surowe osądzenie zbrodniarzy wojennych i zdrajców narodu polskiego ${ }^{11}$. Wyrazem tego był cytowany dekret.

Dekret sierpniowy - jak określano wspomniany przepis - był wymierzony przeciwko hitlerowskim zbrodniarzom wojennym. Na podstawie tego przepisu byli sądzeni i skazani: Rudolf Hoess, komendant obozu w Oświęcimiu, Jurgen Stroop, kat warszawskiego getta, Ludwik Fischer i inni gestapowcy ${ }^{12}$. Jednak te same przepisy stanowiły podstawę prawną do wysuwania oskarżeń i skazywania żołnierzy Armii Krajowej, z których uprawiana w latach czterdziestych i pięćdziesiątych komunistyczna propaganda usiłowała zrobić hitlerowskich kolaborantów. Na podstawie tego przepisu skazani i straceni

${ }^{8}$ Uchwała konferencji poczdamskiej z 2 sierpnia 1945 r. w rozdz. III art. 5 stwierdzała między innymi, że: „Zbrodniarze wojenni oraz te osoby, które brały udział w obmyślaniu lub wykonywaniu przedsięwzięć narodowosocjalistycznych, które pociągały za sobą lub wyraziły się w okrucieństwach albo zbrodniach wojennych, będą aresztowane i oddane pod sąd. Będą aresztowani i internowani przywódcy narodowosocjalistyczni, wpływowi sympatycy nazizmu oraz wysocy urzędnicy organizacji i instytucji nazistowskich, jak również wszelkie osoby niebezpieczne dla okupacji lub jej celów".

9 Dz. U. 1943, Nr 3, poz. 6, S. Jankiewicz, Przygotowania rzadu RP w latach II wojny światowej do procesu zbrodniarzy wojennych. Dekret prezydenta Rzeczypospolitej o odpowiedzialności karnej za zbrodnie wojenne, „Pamięć i Sprawiedliwość”, Warszawa 1997-1997, t. 40. s. 44-56.

10 Zob. P. Szopa, W imieniu Rzeczypospolitej... Wymiar sprawiedliwości Polskiego Państwa Podziemnego na terenie Podokręu AK Rzeszów, Rzeszów 2014.

11 „(...) PKWN za naczelne swe zadanie uważa wzmożenie udziału narodu polskiego w walce o zmiażdżenie Niemiec hitlerowskich. Wybiła godzina odwetu na Niemcach za męki i cierpienia, za spalone wsie, za zburzone miasta, zniszczone kościoły i szkoły, za łapanki, obozy i rozstrzeliwania, za Oświęcim, Majdanek, Treblinkę, za wymordowanie getta".

${ }^{12}$ Do rozpoznania spraw przeciwko osobom, które w okresie drugiej wojny światowej dopuściły się zbrodni na obszarze państwa polskiego, powołano w styczniu 1946 r. Najwyższy Trybunał Narodowy (Dz. U. 1946, Nr 59, poz. 327). Wszystkie wyroki Najwyższego Trybunału Narodowego wraz z uzasadnieniem wydali T. Cyprian i J. Sawicki, Siedem wyroków Najwyższego Trybunału Narodowego, Poznań 1962. Cztery procesy przed NTN, tj. proces Greisera, Hoessa, 40 członków załogi oświęcimskiej oraz Bühlera omówili J. Gumkowski i T. Kułakowski w pracy Zbrodniarze hitlerowscy przed Najwyższym Trybunatem Narodowym, Warszawa 1961. 
zostali: generał August Emil Fieldorf ${ }^{13}$, ps. „Nil” - szef Kedywu-Kierownictwa Dywersji Komendy Głównej Armii Krajowej, Bolesław Kontrym, ps. „Żmudzin”, Bronisław Chajęcki ${ }^{14}$ - zastępca prezydenta Warszawy Stefana Starzyńskiego. Kary dożywotniego więzienia otrzymało wielu żołnierzy Armii Krajowej i uczestników ruchu oporu, w tym m.in. autor głośnej książki Rozmowy z katem Kazimierz Moczarski ${ }^{15}$.

Przestępstwa popełnione w czasie określonym przez dekret sierpniowy rozpoznawały powołane 12 września 1944 r. specjalne sądy karne ${ }^{16}$. Sądy te rozpoznawały sprawy dotyczące zbrodniarzy niemieckich, ale także osób, które występowały przeciwko nowemu ustrojowi. Specjalne sądy karne utworzono przy sądach apelacyjnych (art. 2), początkowo w liczbie trzech, a następnie ośmiu ${ }^{17}$. Prezes sądu podlegał bezpośrednio Ministrowi Sprawiedliwości.

Działalność specjalnych sądów karnych miała zaspokoić naturalną potrzebę części społeczeństwa polskiego, żądającej wymierzenia sprawiedliwości zbrodniarzom niemieckim. Dlatego też zastosowano nadzwyczajne rozwiąza-

13 Zob. M. Fieldorf, L. Zachuta, Generat „Nil” August Emil Fieldorf. Fakty, dokumenty, relacje, Warszawa 1993, S. Marat, J. Snopkiewicz, Zbrodnia. Sprawa generała Fieldorfa-Nila, Warszawa 1989; M. Fieldorf, L. Zachuta, Więzienie i proces generała „,Nila”, „Tygodnik Powszechny” nr 10 z 5 marca 1989 r. J. Wasilewski, Sprawa generała Augusta Emila Fieldorfa, „Palestra”, 1989, nr 11-12; AAN, Prokuratura Generalna (PG), 950, k 45.

14 Zob. AAN, PG, Notatka w sprawie Bronisława Chajęckiego, 1/14.

15 Po raz pierwszyproces Kazimierza Moczarskiego opisała Aniela Steinsberowa w wydanej w Paryżu w 1977 r. publikacji Widziane z ławy obrończej. Autorka, adwokat Moczarskiego, wespół z adwokatem Władysławem Winawerem walczyła przez kilka miesięcy o jego proces rehabilitacyjny, zakończony pełnym sukcesem. Tak o tym pisała „«Błędy i wypaczenia» stalinizmu potępiono i w Związku Radzieckim, i w innych krajach demokracji ludowych, zrehabilitowano wielu niesłusznie skazanych, ale nigdzie poza Polską nie rozegrały się jawne procesy, które odsłoniłyby kulisy represji politycznej. Rehabilitacje przeprowadzono na konwektyklach partyjnych, relacje sprowadzały się do lakonicznych wzmianek «padł ofiarą prowokacji» albo «zrehabilitowany» lub najczęściej «pośmiertnie zrehabilitowany». Nikomu ze skrzywdzonych nie było dane zawołać przed sądem publicznie «oskarżam»! Nigdzie rodzina nie mogła domagać się wznowienia procesów, w których na ławie oskarżonych leżały wiązanki owinięte żałobną krepą. W Polsce stało się inaczej. (...) Nie mała w tym zasługa Kazimierza Moczarskiego, o czym nie powinno się zapominać” A. Steinsbergowa, s. 68-69. Proces Kazimierza Moczarskiego opisał A. K. Kunert, Oskarżony Kazimierz Moczarski, Warszawa 2006, Zob. także A. Machcewicz, Kazimierz Moczarski. Biografia, Kraków 2009.

16 Dz. U. 1944, Nr 4, poz. 21.

17 Rozporządzeniem kierownika Resortu Sprawiedliwości (Dz. U. 1944, Nr7, poz. 35) początkowo utworzono 3 specjalne sądy karne: w Warszawie (z siedzibą tymczasową w Siedlcach), w Krakowie (z siedzibą tymczasową w Rzeszowie) oraz w Lublinie. Utworzenia następnych sądów karnych nie ogłoszono w Dzienniku Ustaw - w Gdańsku, Katowicach, Łodzi, Poznaniu, Toruniu i Wrocławiu. W październiku 1944 r. nastąpiło utworzenie Specjalnego Sądu Karnego w Lublinie oraz prokuratury tego sądu. Na stanowisko kierownika prokuratury Prezydium KRN powołało Henryka Cieśluka (AAN, PG, Kronika Prokuratury PRL, 34/132, k. 11). Ponadto w skład prokuratury weszli: M. Nowakowski, B. Smutek, T. Malinowski i W. Rutański (R. Walczak, Polityka, sądy, prokuratura, Warszawa 1990, s. 81). 
nia w zakresie organizacji działalności sądów specjalnych. Procedura sądowa została znacznie zmieniona: obowiązywała jednoinstancyjność, oskarżenie nie wymagało uzasadnienia, nie przewidywano prowadzenia śledztwa, a jedynie dochodzenie, wyroki ogłaszano natychmiast po naradzie, były one ostateczne i prawomocne (nie podlegały zaskarżeniu), areszt był obligatoryjny. Obowiązywały skrócone terminy procesowe: prokurator powinien w ciągu $14 \mathrm{dni}$ po zamknięciu czynności śledczych przez Urząd Bezpieczeństwa sporządzić akt oskarżenia, a termin rozprawy głównej należało wyznaczyć w ciągu 48 godzin po otrzymaniu aktu oskarżenia. Przepisy dekretu redukowały procesową pozycję sędziów śledczych do roli pomocniczej względem prokuratorów i organów bezpieczeństwa (art. 8). Uzasadniając przyjęte nadzwyczajne rozwiązania, Jerzy Sawicki, znany ówczesny sędzia, pisał: „Ustrój i procedura Sądów Specjalnych stanowią wypadkową emocjonalnych potrzeb chwili i nowych tendencji demokratycznego sądownictwa" "18. Należy w tym miejscu również zaznaczyć, że przyznanie przez „twórców” dekretu szerokich uprawnień prokuratorom, w tym stosowania tymczasowego aresztowania, stanie się wkrótce trwałym elementem odnoszącym się do ustroju sądów i prokuratury.

Dekret o specjalnych sądach karnych wprowadził, wzorem sowieckim, po raz pierwszy do powojennego ustroju sądownictwa powszechnego ławników, których wyznaczało Prezydium KRN ${ }^{19}$ spośród kandydatów przedstawionych przez Wojewódzkie Rady Narodowe (art. 4). Wprowadzenie do powszechnego wymiaru sprawiedliwości czynnika społecznego uzasadniano w sposób następujący: „Sędziowie polscy, choć w większości lojalni w stosunku do obecnej rzeczywistości, są przeważnie jeszcze dalecy od szczerze demokratycznego, względnie socjalistycznego poczucia prawnego. Nieprędko będziemy mieli dostateczną ilość takich sędziów. Dlatego należy dać w sądach karnych przewagę ilościową ławników nad sędziami państwowymi. (...) Dopóki nie będziemy mieli dostatecznej ilości sędziów o socjalistycznym poczuciu prawnym, a to prawdopodobnie nieprędko nastąpi, musimy ich zastępować uspołecznionym elementem ławniczym" ${ }^{20}$. Lawnicy dysponowali dużymi uprawnieniami sędziowskimi. Nie mogli tylko przewodniczyć rozprawie. W składach osobowych zasiadali: przewodniczący i dwóch odpowiednio do potrzeb dobranych ławników, zatem ławnicy mogli przegłosować nawet zawodowego sędziego ${ }^{21}$.

18 J. Sawicki, O prawie sądów specjalnych w: Wymiar sprawiedliwości w odrodzonej Polsce, Warszawa 1945, s. 60.

19 Kandydat na ławnika musiał mieć ukończone 21 lat i wyróżniać się udziałem w walce z okupantem lub odbudowie państwa.

${ }^{20}$ Wystąpienie prezesa Sądu Najwyższego Kazimierza Bzowskiego pt. Potrzeba wydatnego udzialu czynnika spolecznego w wymiarze sprawiedliwości w sprawach karnych, „Państwo i Prawo", 1949, nr 2 (36), s. 61.

21 Składy ławnicze przewidywały także dekrety z 4 listopada 1944 r. O środkach zabezpieczających $w$ stosunku do zdrajców Narodu (Dz. U. 1944, Nr 11, poz. 54). Następnym unormowaniem, 
Komuniści, pozornie wycofując się z bezpośrednich działań w stosunku do sądownictwa powszechnego, lokowali swoich ludzi w nowo tworzonych instytucjach, które za ich pośrednictwem kontrolowali. W ten sposób realizowali dyrektywy siłowej rozprawy z przeciwnikami politycznymi - „dać po mordzie przeciwnikom reżimu, utworzyć obozy koncentracyjne, przeprowadzić procesy pokazowe i publiczne egzekucje faszystów"22. A wszystko to propagandowo określano jako „demokratyzację sądownictwa”. Jednak rzeczywistym motywem tej „demokratyzacji” było ograniczenie samodzielności sędziów zawodowych, wprowadzenie do sądownictwa ludzi oddanych partii komunistycznej i tym sposobem zastosowanie surowych sankcji wobec przeciwników politycznych ${ }^{23}$.

Jak wynika z materiałów źródłowych, ławnicy nie byli przygotowani do pracy $\mathrm{w}$ sądownictwie, nie posiadali wykształcenia prawniczego i dlatego wielu z nich nie potrafiło prawidłowo zastosować obowiązujących przepisów prawa $^{24}$. Ocena ich działalności była negatywna. Dr Juliusz Niekrasz, adwokat z Katowic, mówił: „Wiem, jak trudno jest wysunąć tezę, że sądy ławnicze nie zdały egzaminu i są wręcz, jako instytucja skompromitowane (...) sprawy cywilne i karne winne sądzić wykształceni i nieskazitelni sędziowie zawodowi”25. Współgrała z tym wypowiedź sędziego Budzyna, cywilisty: „zostali oni [ławnicy] wprowadzeni za wzorem radzieckim, i nie zdali egzaminu (...). Dla przykładu podaję, że w czasie rozprawy w sądzie w Cieszynie o ustalenie ojcostwa ławnicy przegłosowali sędziego i powiedzieli, że dziecko musi mieć ojca. Więc należy ustalić, że pozwany jest ojcem pomimo, że nie było na to żadnych dowodów. Oczywiście sprawa ta w postępowaniu rewizyjnym zosta-

w którym pojawili się ławnicy był dekret z 28 lutego 1945 r. o wyłączeniu ze społeczeństwa polskiego wrogich elementów (Dz. U. 1945, Nr 7, poz. 30) oraz ustawa z 6 maja 1945 r. pod tym samym tytułem, z wydanymi w 1945 r. i 1946 r. nowelizacjami. Ustawa z 6 maja 1945 r. Dz. U. 1945, Nr 17, poz. 96 uchylała dekret z 28 lutego 1945 r. Zmiany Dz. U. 1945, Nr 34, poz. 203, Dz. U. Nr 55, poz. 307, Dz. U. Nr 11, poz. 73). W dekrecie z 22 stycznia 1946 r. o Najwyższym Trybunale Narodowym (Dz. U. 1946, Nr 5, poz. 45) i w tzw. małym kodeksie karnym oraz wcześniejszych aktach prawnych (dekret o ochronie Państwa oraz I wersja m.k.k. z 16 listopada 1945 r.) jakie on uchylił, ławnicy sądzili w postępowaniu doraźnym (dekret z 16 listopada 1945 r. Dz. U. 1945, Nr 53, poz. 301). Dalsze rozszerzenie składu ławniczego nastąpiło w 1949 r. po kolejnej nowelizacji procedury karnej oraz w 1950 r. po zreformowaniu ustroju sądów.

22 A. Skrzypek, Mechanizmy uzależnienia. Stosunki polsko-radzieckie 1944-1957, Pułtusk 2002, s. 106; G. Muraszko, A. Noskowa, Sowietskije prisudstwie w Wostocznoj Jewropie 1944-48, w: Awtoritarnyje reżymy w Centralnoj i Wostocznoj Jewropie, Moskwa 1999, s. 88.

23 AAN, Kancelaria Cywilna Prezydenta RP, Kancelaria Rady Państwa, Sprawozdanie stenograficzne z 4 posiedzenia Sejmu Ustawodawczego w dniu 8 lutego 1947 r., 382, t. 1, s. 21.

24 Zob. H. Świątkowki, W. Siedlecki, E. Merz, Udział ludu w wymiarze sprawiedliwości, Warszawa 1954, M. Rybicki, Ławnicy ludowi w sąach PRL, Warszawa 1968.

25 AAN, PG, 951, Wyciąg z protokołu zebrania sprawozdawczo-wyborczego Podstawowej Organizacji Partyjnej przy Prokuraturze Wojewódzkiej w Katowicach odbytego w dniu 27 listopada 1956 r., k. 121. 
ła natychmiast uchylona" ${ }^{26}$. Wypowiedzi te pochodzą z zebrania partyjnego odbytego na popaździernikowej fali odwilży w listopadzie $1956 \mathrm{r}$.

Skutkiem nowych rozwiązań procesowych był brak środków odwoławczych, sędziowie nie zawsze byli przygotowani do rozpoznawania skomplikowanych stanów faktycznych, a ławnicy nie rozumieli przepisów prawa. Założenia ludowego ustawodawcy, że sądy szczególne zapewnią szybki i surowy wymiar kary, nie zostały w pełni zrealizowane. Sygnalizowano potrzebę likwidacji, tłumacząc to nieodpowiednią, zdaniem władz komunistycznych, postawą składów orzekających, które często nie stosowały wysokich sankcji. Dekretem z 17 października 1946 r. ${ }^{27}$ zniesiono specjalne sądy karne, a wszystkie sprawy pozostające w zakresie ich jurysdykcji przekazano sądom powszechnym ${ }^{28}$.

Już w końcowej fazie wojny, w miarę uwalniania kraju spod okupacji niemieckiej, nowa władza wprowadzała istotne zmiany i uzupełnienia do ustawodawstwa karnego z 1932 r. Szczególne znaczenie miał dekret Polskiego Komitetu Wyzwolenia Narodowego (PKWN) z 30 października 1944 r. O ochronie Państwa ${ }^{29}$, który wprowadzał ograniczenie kompetencji sądów powszechnych na rzecz sądów i prokuratur wojskowych w nowej kategorii przestępstw politycznych ${ }^{30}$. Nastąpiło stopniowe zawieszanie regulacji kk z 1932 r. Ponadto kompetencji sądów wojskowych podlegały przestępstwa określone w art. 85-99 i 101-103 kodeksu karnego Wojska Polskiego, w tym popełnione przez osoby cywilne ${ }^{31}$. Przyjęte $w$ dekrecie rozwiązania umożliwiające sądom wojskowym sądzenie osób cywilnych przetrwały do kwietnia 1955 r.

${ }^{26}$ Ibidem, k. 129.

27 Dz. U. 1946, Nr 59, poz. 324

${ }^{28}$ Uchylono również przepisy dekretu z 4 listopada 1944 r. o środkach zabezpieczajacych oraz ustawę z 6 maja 1945 r. o wyłączeniu ze społeczeństwa polskiego wrogich elementów. Zakres odpowiedzialności został unormowany w dekrecie z 28 czerwca 1946 r. o odpowiedzialności karnej za odstępstwo od narodowości w czasie wojny 1939-1945 Dz. U. 1946, Nr 41, poz. 237.

29 Dz. U. 1944, Nr 10, poz. 50.

${ }^{30}$ Tzw. zbrodnie stanu, za które sądzona była ludność cywilna zostały określone w nast. aktach prawych: art. 1-9 z 31 sierpnia 1944 r. o wymiarze kary dla faszystowsko-hitlerowskich zbrodniarzy winnych zabójstw i znęcania się nad ludnościa cywilna i jeńcami oraz dla zdrajców Narodu Polskiego (Dz. U. 1944, Nr 4, poz. 16); art. 85-99 i 101-103 Kodeks Karny Wojska Polskiego z 23 września 1944 r. (Dz. U. 1944, Nr 6, poz. 27); art. 1-13 dekretu z 30 października 1944 r. o ochronie Państwa (Dz. U 1944, Nr 10, poz.50); art. 1-12 dekretu z 16 listopada 1945 r. o przestępstwa szczególnie niebezpiecznych w okresie odbudowy Państwa (Dz. U. 1945, Nr 53, poz. 300); 1-18 dekretu z 13 czerwca 1946 r. o przestępstwa szczególnie niebezpiecznych w okresie odbudowy Państwa zwany małym kodeksem karnym (Dz. U. 1946, Nr 30, poz. 192).

${ }^{31} \mathrm{Na}$ mocy art. 1 dekretu o ochronie Państwa z naruszeniem podstawowej zasady nullum crimem sine lege poena li anteriorii, skazywano żołnierzy AK. PKWN 24 sierpnia 1944 r. wydał dekret o rozwiazaniu tajnych organizacji wojskowych na terenach wyzwolonych (Dz.U. 1944, $\mathrm{Nr} 3$, poz. 12), który ogłaszał rozwiązanie „wszystkich” organizacji wojskowych jako pozbawionych dalszych racji bytu. Ponadto dekret wprowadzał obowiązek przekazania broni WP. Żołnierze AK i innych organizacji podległych władzom polskim w kraju i na emigracji nie zastosowali się do dekretu, ponieważ oznaczałoby to złamanie przysięgi wojskowej. Zob. E. Romanowska, Syl- 
Dekret $O$ ochronie Państwa zapoczątkował niezwykle represyjny kierunek zmian w polskim prawie karnym, dla którego pierwowzór zapewne stanowiły unormowania zapożyczone z ustawodawstwa niemieckiego. „Ludowy" ustawodawca wzorował się, przynajmniej częściowo, na represyjnym rozporządzeniu Hansa Franka, które dopuszczało wymierzanie kary śmierci ${ }^{32}$. Wskazać należy tytuł obu aktów prawnych: rozporządzenie celem zwalczania czynów gwaltu w Generalnym Gubernatorstwie oraz dekret o ochronie Państwa, ich zbliżoną obszerność; w obu aktach ustanawia się nowe rodzaje czynów zabronionych (przestępstw) dotyczących „ochrony Państwa”, występowanie podobnych przestępstw; w obu aktach przewidziano, że sądami właściwymi do rozpoznawania przestępstw w nich opisanych są sądy szczególne: wojskowe w dekrecie o ochronie Państwa oraz „doraźne wojskowe” lub „doraźne policyjne” w rozporządzeniu Hansa Franka. Zbieżności jest tyle, że nie sposób przyjąć, że „ludowy” ustawodawca nie wzorował się, przynajmniej częściowo, na rozporządzeniu Hansa Franka

Cytowany dekret zapoczątkował niezwykle represyjny kierunek zmian w polskim prawie karnym. Należy zauważyć, że na osiemnaście artykułów, we wszystkich jedenastu przepisach ${ }^{33}$ o charakterze materialno-prawnym

wetka bohatera Polski Podziemnej Porucznika Aleksandra Kielasińskiego, w: Różnymi drogami do niepodległości. Studia z historii najnowszej, red. M. Żuławnik, B. Świtalska, Warszawa 2014, s. 177-195; R. Wnuk, Lubelski Okręg AK DSZ i WiN 1944-1947, Warszawa 2000, s. 27. Wykonanie prawomocnego wyroku sądu wojskowego w części dotyczącej przepadku mienia na rzecz Skarbu Państwa należało do Prokuratorii Generalnej Rzeczypospolitej. Zob. Archiwum Instytutu Pamięci Narodowej Biuro Udostępniania i Archiwizacji Dokumentów (AIPN BU), 883/1, Okólnik Naczelnego Szefa Sądownictwa Wojennego, generała brygady Aleksandra Tarnowskiego, Nr WSW 08/44 do szefów wojskowych sądów i prokuratur, 8 XII 1944 r., k. 37.

$32 \S 1$. Kto dopuszcza się czynu gwałtu przeciw Rzeszy Niemieckiej lub Niemieckiej władzy zwierzchniej, wykonywanej w Generalnym Gubernatorstwie, ulega karze śmierci.

$\S 2$. Kto umyślnie uszkadza urządzenia władz Niemieckich, rzeczy służące do pracy władzom Niemieckim lub urządzenia użyteczności publicznej, ulega karze śmierci.

$\S 3$. Kto nawołuje lub zachęca do nieposłuszeństwa rozporządzeniom władz Niemieckich, podlega karze śmierci.

$\S 4$. Kto dopuszcza się czynu gwałtu przeciw Niemcowi powodu jego przynależności do narodu Niemieckiego, ulega karze śmierci. śmierci.

$\S 5$. Kto dopuszcza się umyślnego podpalenia i przez to uszkadza majątek Niemca, ulega karze

$\S 8$. Kto umawia się do popełnienia przestępstwa, określonego w $\S 1-5$, kto w tym celu wchodzi w poważne porozumienie $\mathrm{z}$ innymi, kto ofiaruje się do popełnienia takiego przestępstwa lub zaofiarowanie takie przyjmuje, ulega karze śmierci.

§ 9. Kto otrzymawszy wiadomość o zamiarze popełnienia przestępstwa, określonego w $\S 1-5$, zaniecha władzy lub osobie, której przestępstwo to grozi, niezwłocznie lub w takim czasie donieść o nim, aby można było zamierzonemu przestępstwu zapobiec, ulega karze śmierci. Rozporządzenie celem zwalczania czynów gwałtu w Generalnym Gubernatorstwie z 31 października 1939 r. Dziennik Ustaw Rzeszy, I, 2077.

${ }^{33}$ Kara śmierci groziła za: udział w związku, którego celem było obalenie demokratycznego ustroju (art. 1), udaremnianie reformy rolnej (art. 2), za gwałtowny zamach na organy państwa (art. 3), za posiadanie amunicji lub broni (art. 4), za sabotaż (art. 5), za posiadanie aparatu radiowego 
ustawodawca dopuszczał wymierzenie kary śmierci. Wskazać należy bardzo istotne cechy omawianego dekretu - jego elastyczność i nieostrość przepisów, tzn. przepisy te nie odpowiadały opisowi poszczególnych rodzajów zachowań zagrożonych sankcją karną. Dlatego też zostały tak sformułowane, aby można było nimi objąć jak najszerszą liczbę osób i były interpretowane przez ustawodawcę dowolnie,

w zależności od okoliczności związanych z aktualnymi potrzebami politycznymi. Wszelkie kontakty międzyludzkie interpretowano jako przestępstwo zbrodni lub szpiegostwa, np. udział w związku tajnym, udział w związku przestępczym, udział w zebraniu bez zezwolenia. Kontakty te poddane zostały kontroli władz bezpieczeństwa. Naturalne dążenie do wolności lub swobody wypowiedzi zapisane zostało w normie prawnej jako tzw. szeptanki lub zakaz posiadania odbiorników radiowych.

Cechą charakterystyczną dekretu był brak zróżnicowania sankcji. Wszystkim dyspozycjom przypisano sankcje ujęte w najszerszym zakresie od 6 miesięcy więzienia do kary śmierci włącznie, z obligatoryjną karą utraty praw publicznych i obywatelskich praw honorowych. Dekret groził karą przepadku mienia w całości - obligatoryjnie w razie skazania na karę śmierci - lub fakultatywnie w przypadku kary więzienia (art. 13) ${ }^{34}$. Wyrok był niezaskarżalny ${ }^{35}$. Dekret o ochronie Państwa nie przewidywał kary dożywotniego pozbawienia wolności.

Druga część dekretu wprowadzała nowe organa właściwe w sprawach opisanych w części pierwszej stanów faktycznych. Na mocy art. 16 dekretu o ochronie Państwa ${ }^{36}$ postępowanie przygotowawcze prowadzone było przez

(art. 6), za wywieranie wpływu na czynności rad narodowych (art. 7), za zakładanie związku mającego na celu przestępstwo, albo którego istnienie miało pozostać tajemnicą wobec władzy państwowej (art. 8), za przywłaszczenie lub kradzież (art. 9), za uchylanie się od obowiązku świadczenia osobistego lub rzeczowego (art. 10), za niedoniesienie o przestępstwach określonych w dekrecie (art. 11).

34 Art. 13 Dekretu o ochronie Państwa. Sąd orzeka przepadek całego mienia w razie skazania na karę śmierci. W innych przypadkach sąd może orzec przepadek całego lub części mienia. Dz. U 1944, Nr 10, poz. 50.

35 Przesłanki, które decydowały o braku możliwości zmiany wadliwego orzeczenia, to: brak nadzoru prokuratorskiego, ograniczenia w stosowaniu procedury ułaskawienia, natychmiastowa wykonalność. Dekret o ochronie Państwa jako prawo epizodyczne, tj. na czas wojny, uchylony został przez art. 40 dekretu o przestepstwach szczególnie niebezpiecznych w okresie odbudowy państwa (Dz. U. Nr 53, poz. 300).

${ }^{36}$ Art. 16 dekretu o ochronie Państwa stanowił: 1. Do rozpoznania spraw o przestępstwa, objęte niniejszym dekretem oraz wymienione w art. 85-99 i art. 101-103 (zbrodnie stanu) kk WP właściwe są sądy wojskowe; 2. Przeprowadzenie dochodzenia w sprawach wymienionych w pkt. 1 należy do organów bezpieczeństwa publicznego, o ile nie zostało lub nie zostanie wszczęte postępowanie przez prokuratora wojskowego; 3. Po ukończeniu dochodzenia organa bezpieczeństwa publicznego przekazują akta spraw właściwemu prokuratorowi wojskowemu. Dz. U. 1944, Nr 10, poz. 50. Należy zaznaczyć, że już Rozkaz dzienny nr 60 z 24 lipca 1943 r. wydany przez dowódcę 1 Dywizji Piechoty im. Tadeusza Kościuszki w ZSRR, płk. Zygmunta Berlinga, dotyczący postępowania w sprawie przestępstw i wypadków nadzwyczajnych wskazywał, że ,śledztwo wszczynane 
organa bezpieczeństwa publicznego. Jak tłumaczono, prowadzenie śledztwa dlatego wchodziło w zakres obowiązków organów bezpieczeństwa publicznego i Informacji Wojskowej, ponieważ ich podstawowym, szerszym zadaniem było ,wykrywanie przestępstw jeszcze nie nieujawnionych, zwłaszcza wszelkich przygotowań do przestępstw"37. Ten kierunek działań aparatu bezpieczeństwa wyodrębnił czynności operacyjne i wyjaśniające, które nie podlegały kontroli ani prokuratury, ani sądu, a należały do wyłącznej kompetencji funkcjonariuszy bezpieczeństwa publicznego i Informacji Wojskowej ${ }^{38}$. W rzeczywistości odpowiedni departament MBP prowadził rozpracowanie agenturalne danego środowiska, np. na podstawie akt śledczych (repertorium śledcze) już aresztowanego człowieka następowały dalsze aresztowania nadzorowane przez Departament Śledczy MBP (od rewizji, zatrzymania po sformułowanie aktu oskarżenia). Warto też zwrócić uwagę, że dekret nie przewidywał w ogóle klasycznego śledztwa. W ten sposób wykluczał z postępowania przygotowawczego niezawisłego sędziego śledczego. Jego kompetencje przejęli funkcjonariusze organów bezpieczeństwa publicznego i Informacji Wojskowej.

Należy również pamiętać, że już w latach trzydziestych XX w. pojawiły się głosy żądające reformy postępowania karnego ${ }^{39}$. Na III Zjeździe Prawników Polskich w Katowicach w 1936 r. Mieczysław Siewierski, ówczesny prokurator, domagał się likwidacji instytucji sędziego śledczego i proponował całe śledztwo przekazać prokuratorowi. W 1968 r. w prywatnym liście do Stanisława Waltosia tłumaczył, że nie chodziło mu o faszyzowanie kraju, czyli o branie społeczeństwa „za twarz”. Zależało mu na usprawnieniu procedury. Jego zdaniem sędzia śledczy nie był sprawny ${ }^{40}$. Wysuwane w latach trzydziestych propozycje likwidacji instytucji sędziego śledczego zostały wprowadzone w drugiej połowie lat czterdziestych. W 1949 r. władze zlikwidowały instytucję sędziego śledczego. Wkrótce to samo uczyniono z instytucją sędziego śledczego w pozostałych państwach należących do bloku wschodniego ${ }^{41}$.

jest przez prokuratora wojskowego lub przez wydział Informacji Wojskowej, przy czym śledztwo w sprawach zdrady Narodu, szpiegostwa, pomocy państwu nieprzyjacielskiemu, aktu terroru, sabotażu, zaboru broni palnej obligatoryjnie przekazano do prowadzenia przez wydział Informacji Wojskowej". Centralne Archiwum Wojskowe (CAW), III.7.486, Rozkaz dzienny nr 60 z 24 lipca 1943 r., k. 53-54.

37 AAN, PG, 4/551, Polityczno-prawna istota nadzoru nad śledztwem, k. 3.

38 Ibidem.

39 S. Zalewski, Dwa Kryzysy. Reforma sądownictwa karnego, „Głos Sądownictwa”, 1932, nr 1 , s. 6 .

40 S. Waltoś, Sędzia śledczy - rys historyczny, [w:] Nowy model postępowania przygotowawczego - sędzia śledczy, Warszawa 2010, s. 15-21.

41 Obecnie nawet kraje, w których ta instytucja ma długą tradycję, odchodzą od instytucji klasycznego sędziego śledczego i zmierzają w kierunku sędziego do spraw postępowania przygotowawczego. W 1974 r. zlikwidowano tę instytucję w Republice Federalnej Niemiec. Zastąpiono ją instytucją sędziego do spraw dochodzenia (Ermittlungsrichter). Funkcję tę pełni sędzia sądu powia- 
Dalsze ograniczenie sądów i właściwości przyniósł dekret z 13 czerwca 1946 r. o przestępstwach szczególnie niebezpiecznych w okresie odbudowy Państwa ${ }^{42}$, tzw. mały kodeks karny (mkk). Art. 68 dekretu zawieszał przepisy kk z $1932 \mathrm{r}$. Wszystkie przestępstwa zdefiniowane $\mathrm{w}$ rozdziale I dekretu podlegać miały właściwości sądów wojskowych ${ }^{43}$. Utrzymano również właściwość tych sądów wobec osób cywilnych, które dopuściły się zbrodni stanu określonych w art. 85-88 i 102 § 2 kk WP ${ }^{44}$. Pozostałe przestępstwa wymienione w tym dekrecie były rozpatrywane przez specjalne wydziały utworzone przy sądzie okręgowym. W myśl art. $55 \mathrm{mkk}$, do prowadzenia postępowania przygotowawczego uprawnione były organa bezpieczeństwa publicznego, a nadzór nad nimi sprawował prokurator wojskowy. W ten sposób wzmocnieniu

towego (Amtsgericht) lub innego wyższego sądu, a nawet Bundesgerichtshofu. Wydaje on wszelkie kluczowe decyzje w zakresie wolności osobistej oraz kontroli decyzji wydawanych przez organy niesądowe w toku postępowania, które nazywa się dochodzeniem. Prokurator i policja odpowiadają za przebieg dochodzenia. 1 stycznia 2000 r. we Francji wprowadzono nową instytucję - sędziego do spraw wolności (juge de libera de la defension), mającego wysoką rangę prezesa lub wiceprezesa „trybunału wielkiej instancji”, który decyduje o stosowaniu środków zapobiegawczych. Obowiązkiem sędziego do spraw wolności jest dbanie o przestrzeganie praw obywatelskich przez nadzór nad samymi czynnościami i wykonywanie tychże czynności dowodowych. W $2008 \mathrm{r}$. instytucje sędziego śledczego zlikwidowano w Austrii oraz w tych kantonach szwajcarskich, w których ona istniała. Nie ma również tej instytucji we Włoszech. W Rosji w nowym Kodeksie (postępowania karnego) również nie zdecydowano się przywrócić znanego z carskich czasów sudiebnogosledowatiela. Pozostawiono tylko funkcjonariusza śledczego, sledowatiela, niepełniącego żadnych funkcji judykacyjnych. Należy przy tym podkreślić, że ma on więcej uprawnień niż jego odpowiednik w ZSRR.S. Waltoś, Sędzia śledczy - rys historyczny, [w:] Nowy model postępowania przygotowawczego - sędzia śledczy, Warszawa 2010.

42 Dz. U. 1946, Nr 30, poz. 192. Akt ten zachował dawną nazwę O przestęsstwach szczególnie niebezpiecznych w okresie odbudowy Państwa, z 16 listopada 1945 r., dlatego że, po pierwsze, podkreślono utrzymanie ciągłości z dekretem z 16 listopada 1945 r., po drugie nowy dekret powtarzał większość przestępstw ze starego dekretu, jak również podkreślono, że dotyczy okresu odbudowy państwa. Dekret wszedł w życie z dniem ogłoszenia, tj. 12 lipca 1946 r. i obowiązywał do 31 grudnia 1969 r. Równocześnie z wydaniem dekretu straciły moc prawną przepisy dekretu z 16 listopada 1945 r. (art. 69).

${ }^{43}$ Art. $51 \mathrm{mkk}$.

${ }^{44}$ - kto usiłuje pozbawić państwo polskie niepodległego bytu lub oderwać część jego obszaru, podlega karze więzienia od lat 10 do 15 albo karze śmierci (art. 85);

- kto usiłuje przemocą usunąć ustanowione organa władzy zwierzchniej narodu albo zagarnąć ich władzę, podlega karze więzienia na czas nie krótszy od lat 5 albo karze śmierci (art. 86 §);

- kto usiłuje przemocą zmienić ustrój państwa polskiego, podlega karze więzienia na czas nie krótszy od lat 5 albo karze śmierci (art. $86 \S 2$ );

- kto czyni przygotowania do popełnienia przestępstwa, określonego w art. 85 lub 86, podlega karze więzienia (art. 87);

- kto w celu popełnienia przestępstwa, określonego w art. 85 lub 86 wchodzi w porozumienie z innymi osobami, podlega karze więzienia (art. $88 \S 1$ );

- nie podlega karze, kto wziąwszy udział w porozumieniu, doniesie o nim władzy, powołanej do ścigania przestępstw, zanim władza dowiedziała się o porozumieniu i zanim wynikły jakiekolwiek ujemne skutki dla państwa. $Z$ bezkarności nie korzysta, kto doprowadził do powstania takiego porozumienia (art. $88 \S 2)$. 
uległa pozycja prokuratora, który w postępowaniu przygotowawczym otrzymał kompetencje sędziego śledczego (art. $58 \mathrm{mkk}$ ) i organów bezpieczeństwa publicznego (art. 57 pkt $4 \mathrm{mkk}$ ). Z postępowania przygotowawczego został wyeliminowany sędzia śledczy. Sprawy o te przestępstwa (za wyjątkiem szpiegostwa) powróciły do właściwości sądów powszechnych na początku maja 1955 r. Rozpoznawanie spraw o pozostałe przestępstwa kodeks pozostawiał sądom okręgowym, z tym, że orzekanie miało następować w składzie jednego sędziego i dwóch ławników. Prokurator powszechny otrzymał w postępowaniu przygotowawczym szereg nowych uprawnień, m.in. prawo stosowania środków zapobiegawczych (łącznie z tymczasowym aresztowaniem) oraz prawo przedłużania aresztu w toku dochodzenia.

W obszarze prawa karnego istotnym krokiem w kierunku ograniczania właściwości sądów powszechnych w kategorii przestępstw gospodarczych był dekret z 16 listopada 1945 r. o utworzeniu i zakresie działania Komisji Specjalnej do walki z nadużyciami i szkodnictwem gospodarczym ${ }^{45}$, który szybko stał się instrumentem represji wobec wrogów ustroju komunistycznego. Odrzucona koncepcja utworzenia ,,sądów ludowych" ${ }^{46}$ w praktyce nie oznaczała zaniechania przez „ludowego" ustawodawcę prób przejęcia kontroli nad aparatem wymiaru sprawiedliwości. Rzeczywiste ramy funkcjonowania Komisji zostały ustalone w czasie obrad Biura Politycznego KC PPR ${ }^{47}$. Komisja Specjalna zaopatrzona w szerokie uprawnienia miała za zadanie wykrywać i ścigać - bezpośrednio lub poprzez terenowe delegatury - przestępstwa godzące w interesy życia gospodarczego lub społecznego państwa, a zwłaszcza przywłaszczenia, grabieże mienia publicznego lub będącego pod zarządem publicznym, korupcję, łapownictwo, spekulację i tzw. szabrownictwo. Organy Komisji Specjalnej i jej delegatury posiadały odpowiednie uprawnie-

45 Dz. U. 1945, Nr 53, poz. 302.

46 T. Torańska, Oni, Warszawa 1997, s. 314. Wywiad z L. Chajnem ówczesnym wiceministrem sprawiedliwości.

47 Protokoty z posiedzeń Biura Politycznego KC PPR 1944-1945, oprac. A. Kochański, Warszawa 1995, s. 15; Komisja Specjalna do Walki z Nadużyciami i Szkodnictwem Gospodarczym 1945-1954. Wybór dokumentów, wstęp i oprac. D. Jarosz i T. Wolsza, Warszawa 1995, s.172. Strukturę Komisji oparto na komisji i Biurze Wykonawczym działającym na szczeblu centralnym oraz delegaturach stałych i czasowych. Przewodniczącym Komisji został członek Prezydium KRN Roman Zambrowski. Ponadto w skład Komisji wchodzili: dr Kazimierz Jasiński (I zastępca przewodniczącego, przedstawiciel KC ZZ), Henryk Gacki (II zastępca przewodniczącego), prokurator Sądu Najwyższego, przedstawiciel Prezesa Rady Ministrów), Leon Chajn (podsekretarz stanu w Ministerstwie Sprawiedliwości), Eugeniusz Gajewski (przedstawiciel Związku Samopomocy Chłopskiej), Jan Grubecki (przedstawiciel Biura Kontroli przy Prezydium KRN), Mieczysław Mietkowski (przedstawiciel MBP), Marceli Porowski (przedstawiciel MAP) oraz gen. Konrad Świetlik (przedstawiciel MON). Dyrektorem Biura Wykonawczego Komisji mianowany został przedstawiciel Centralnej Komisji Związków Zawodowych dr Kazimierz Jasiński, jego zastępcą prokurator Henryk Gacki. Skład Komisji na podstawie: Komisja Specjalna do Walki z Nadużyciami..., s. 15. Szerzej na temat Komisji zob. P. Fiedorczyk, Komisja Specjalna do Walki z Nadużyciami i Szkodnictwem Gospodarczym. Studium historycznoprawne, Białystok 2002. 
nia organów sądowych (sędziów śledczych) ${ }^{48}$ i prokuratorskich, a więc m.in. stosowanie tymczasowego aresztowania $\mathrm{w}$ zakresie orzekania o skierowaniu osoby „do pracy przymusowej”. W rzeczywistości pracownicy Komisji byli $\mathrm{w}$ jednej osobie oskarżycielami i sędziami ${ }^{49}$.

W sprawach o przestępstwa ścigane przez Komisję Specjalną orzekały sądy właściwe według obowiązujących przepisów prawa, jednakże Komisja Specjalna mogła nie kierować sprawy do sądu, lecz po przeprowadzeniu dochodzenia rozstrzygnąć ją we własnym zakresie, przy tym mogła nakazać umieszczenie sprawcy w obozie pracy na okres do dwóch lat. Warunkiem takiego rozstrzygnięcia sprawy było stwierdzenie, że działanie sprawcy pozostawało „W związku ze wstrętem do pracy” albo „stwarzało niebezpieczeństwo popełnienia nadużyć lub dopuszczenia się szkodnictwa gospodarczego" (art. 10 pkt 2). W tym kontekście dyspozycje ujęte w dekrecie wskazywały na istnienie winy lub tylko prognozy popełnienia czynu zabronionego. Fakt ten świadczy o naruszeniu podstawowych norm prawa karnego - pozbawienie wolności możliwe było wyłącznie na mocy wyroku sądowego, natomiast karę można wymierzyć jedynie w wypadku popełnienia czynu przez osobę, wobec której prowadzono postępowanie, a nie na podstawie negatywnych prognoz. Wynika stąd jednoznacznie, że regulacje przepisów z okresu Drugiej Rzeczypospolitej, będących nadal podstawowym źródłem prawa karnego, były interpretowane przez ustawodawcę w nowym duchu, tak aby można było dostosować je do nowych warunków politycznych, umożliwiających dowolne kształtowanie represyjnej polityki karnej. Potwierdził to Andrzej Jakubowski, w latach 1948-1950 inspektor w Delegaturze Komisji Specjalnej w Łodzi, który pisał: „W ówczesnej Delegaturze z inicjatywy Biura Wykonawczego Komisji Specjalnej powstał tzw. wydział do spraw problemowych. Wydział ten nie będąc ustanowiony, jako wyraźna administracyjna komórka Delegatury skupiał w sobie sprawy, w których zadaniem śledztwa było unieszkodliwienie, przez skazanie ludzi wrogich ówczesnemu Kacykowskiemu Kierownictwu partii z placówek, w których zajmowali stanowiska. W sprawach tam prowadzonych zakładano z góry, że ktoś jest winny, a potem prowadzono śledztwo, w wyniku którego wielokrotnie skazywano bez żadnych dowodów w trybie tzw. postępowania obozowego"50. Kilka lat później, w 1957 r. Komisja badania odpowiedzialności przeciwko prokuratorom, którzy łamali obowiązujące przepisy prawa, stwierdziła, że: „W Generalnej Prokuraturze szeroko stosowana była praktyka kierowania spraw do Komisji Specjalnej $\mathrm{z}$ wnioskiem o orzeczenie kary dwóch lat obozu bez zaliczenia tymczasowego

48 Dz. U. 1946, Nr 23, poz. 149.

49 Zob. AAN, PG, 951, Wyciąg z protokołu zebrania sprawozdawczo-wyborczego Podstawowej Organizacji Partyjnej przy Prokuraturze Wojewódzkiej w Katowicach odbytego w dniu 27 listopada 1956 r., k. 152.

50 AAN, PG, 951, List Andrzeja Jakubowskiego do Prokuratora, 7 XI 1956 r., k. $73-75$. 
aresztowania. Praktyka ta stosowana była wówczas, gdy okres tymczasowego aresztowania trwał przez okres dłuższy, czasem ponad dwa lata, a chodziło o dalsze pozbawienie wolności aresztowanego. (...) skutkiem czego osoby aresztowane przetrzymywane były faktycznie po kilka lat, nawet do pięciu lat" ${ }^{51}$. Tak scharakteryzował ten okres Jerzy Mering, przyszły obrońca z urzędu gen. Augusta Emila Fieldorfa, ps. „Nil”, a w latach 1945-1946 dyrektor w Centralnym Zjednoczeniu Przemysłu Winiarskiego: „Był to okres bardzo ciężkich zmagań z szabrownikami. (...) Musiałem zamykać (kazać aresztować) szereg dyrektorów we Wrocławiu, Raciborzu, Wolsztynie i samym Poznaniu" 52 .

16 listopada 1945 r. wydany został dekret o postępowaniu doraźnym ${ }^{53}$, który stanowił m. in., że również w tym postępowaniu orzeka sąd okręgowy w składzie ławniczym, a obligatoryjnie aresztowanie podejrzanego zarządza prokurator.

Nowa władza zgłaszała również postulat wprowadzenia do sądownictwa powszechnego przedstawicieli społeczeństwa. Rada Państwa 22 lutego 1946 r. wydała dekret Prawo o sądach obywatelskich ${ }^{54}$ regulujący drobne sprawy wynikające $\mathrm{z}$ konfliktów międzyludzkich ${ }^{55}$. Koncepcja ta wzorowana była częściowo na instytucji sądów robotniczych i włościańskich działających w ZSRR. Pierwsze sądy obywatelskie powołano 1 stycznia 1948 r. ${ }^{56}$ Członkami tych sądów byli w większości robotnicy i rolnicy - 534 osoby, pracownicy umysłowi - 165 osób. Wykształcenie niższe niż średnie miało aż 525 osób.

51 AAN, PG, 958, Akta sprawy przeciwko prokuratorowi Stefanowi Kalinowskiemu, k. 1.

52 AAN, KC PZP, Centralna Kartoteka, CK XX/26627, Akta osobowe Jerzego Meringa, k. 22. Zob. także W. Bartoszewski, Pod prą. Moje środowisko niepokorne 1945-55. Wspomnienia dziennikarza i więźnia, oprac. M. Komar, Warszawa 2011, s. 216-228.

53 Dz. U. 1945, Nr 53, poz. 301, przepisy te były regulowane trzykrotnie - dekretem z 13 czerwca 1946 r. Dz. U. 1946, Nr 30, poz. 193 o zmianie dekretu z 16 listopada 1945 r. o postępowaniu doraźnym; ustawą z 27 kwietnia 1949 r. o zmianie dekretu o postępowaniu doraźnym Dz. U. 1949, Nr 32, poz. 239; tekst jednolity z 18 maja 1949. Dz. U. 1949, Nr 33, poz. 244.

54 Dz. U. 1946, Nr 8, poz. 64.

55 Wśród spraw karnych poddanych orzecznictwu sądów obywatelskich obok ustawy z 14 kwietnia 1937 r. o szkodnictwie leśnym i polnym (Dz. U. 1937, Nr 30, poz. 224) i ustawy z 21 marca 1931 r. o ograniczeniach $w$ sprzedaży, podawaniu i spożyciu napojów alkoholowych (Dz. U. 1931, Nr 51, poz. 423), były sprawy o przestępstwa z kodeksu karnego ścigane w trybie oskarżenia prywatnego.

56 Rozporządzenie Ministra Sprawiedliwości z 14 listopada 1947 r. w sprawie regulaminu urzędowania: Dz. U. 1947, Nr 71, poz. 437, o odznace stużbowej dla sędziego obywatelskiego, Dz. U. 1947, Nr 71, poz. 438, o specjalnych oplatach sądowych $w$ postepowaniu przed sądami obywatelskimi, Dz. U. 1947, Nr 71, poz. 439, o opłatach od czynności prawnych dokonanych przed sędziami obywatelskimi, Dz. U. 1947, $\mathrm{Nr} 71$, poz. 440, o wynagrodzeniu sędziów obywatelskich i ławników, Dz. U. 1947, Nr 71, poz. 441. Postępowanie przed sądem obywatelskim charakteryzowało się uproszczoną procedurą oraz działaniem sędziego zmierzającym do pojednania stron. Funkcję oskarżyciela publicznego pełnił przedstawiciel gminnego zarządu, sołtys lub milicjant. W myśl art. 37 dekretu sąd nie był związany regułami dowodowymi, a orzeczenie opierał na „,swobodnej ocenie wszelkich okoliczności sprawy". 
Podstawowym kryterium przyjmowania kandydatów do sądów ludowych była przynależność partyjna: członków PPR było 272 osoby, PPS 144. Członkowie PPR i PPS mieli zdecydowaną przewage jako sędziowie obywatelscy i zastępcy sędziów obywatelskich, było ich 109 osób, członków SL, SD i bezpartyjnych było 30 osób. PSL i SP nie miały swoich przedstawicieli wśród sędziów obywatelskich i ich zastępców, co było wynikiem doboru ludzi do tych sądów; jedynie 6 ławników było członkami PSL i SP57. 19 listopada 1948 r. pracownik KC PZPR wizytujący sądy ludowe w woj. rzeszowskim stwierdził, że sądy obywatelskie łamią biurokratyzm, pieniactwo i pasożytnictwo adwokackie, „są to formy klasowej, demokratycznej (...) sprawiedliwości (...), są to formy walki klasowej na odcinku wymiaru sprawiedliwości"58. Sprawozdanie zawierało też ujemne oceny. Zdaniem wizytującego w wielu przypadkach ,klasową linię i ocenę wymiaru sprawiedliwości utożsamia się z przynależnością partyjną i to stanowi podstawę oceny konkretnej sprawy”. Na dowód przytacza fragment opisu działalności sądu obywatelskiego w Tyczynie (woj. rzeszowskie) z 14 sierpnia 1948 r.: „Członków PPR i Walki Młodych sąd zawsze bierze w obronę (...), nawet gdy coś zrobi i występuje jako oskarżony, wyznaczamy z urzędu obrońcę"59. Sądy obywatelskie zakończyły swoją działalność w 1954 r. ${ }^{60}$

Analiza scharakteryzowanych powyżej rozwiązań prowadzi do następujących konkluzji: pomimo, iż niektóre kategorie spraw o charakterze politycznym i częściowo gospodarczym zostały wyeliminowane z zakresu działania sądownictwa powszechnego, to jednak w kręgu działania tego sądownictwa pozostało wiele spraw ogromnie istotnych z punktu widzenia społecznego, gospodarczego, a nawet politycznego. Fakt ten w dalszym ciągu niepokoił komunistów. Ponadto niepokoiło ich istnienie obok siebie dwóch trybów procedury sądowej, tj. tej przedwrześniowej i tej nowej, powojennej. Nawet pomimo zapewnień przedstawicieli nauki prawa, iż w Polsce komunistycznej obowiązuje jeden system prawny ${ }^{61}$.

57 R. Walczak, op. cit., s. 57.

58 Ibidem.

59 Ibidem. Dekretem z 21 kwietnia 1948 r. (Dz. U. 1948, Nr 23, poz. 153) zostały znowelizowane przepisy prawa o sądach obywatelskich. Rozszerzono właściwość spraw cywilnych, natomiast w sprawach karnych wszczęcie postępowania następowało na podstawie aktu oskarżenia wniesionego przez oskarżonego lub milicję, której funkcjonariusz uczestniczył obok lub w zastępstwie przedstawiciela zarządu gminy. Doniesienie organów administracyjnych mogło stanowić podstawę wszczęcia postępowania. W postępowaniu przed sądami obywatelskimi wyłączono udział adwokatów w charakterze pełnomocników i obrońców sądowych. Powodem nowelizacji były sygnały o niskim poziomie wykształcenia sędziów, którym prawnicy zarzucali w prowadzeniu rozpraw błędy.

${ }^{60}$ Ustawa z 25 września 1954 r. Dz. U. 1954, Nr 43, poz. 191.

61 M. Muszkat, Jeden czy dwa systemy prawne?, „Przegląd Notarialny”, 1949, z. 7-8; J. Sawicki, W. Walawski, Zmiana istoty prawa czy stosunku do prawa. Rzecz o praworzadności, „Wojskowy Przegląd Prawniczy”, 1945, z. 2; G. Auscaler, W. Wolter, Prawo karne, w: Dziesięciolecie prawa Polski Ludowej 1944-1954. Zbiór studiów, red. L. Kurowski, Warszawa 1955, s. 280. 
III. Krytyka sądownictwa powszechnego nasiliła się po 1948 r. Sądownictwo powszechne krytykowano nie tylko na łamach czasopism, ale także w dokumentach partyjnych. Podnoszona była kwestia radykalnej zmiany powszechnego wymiaru sprawiedliwości. Pisano, że zarówno sądy, jak i prokuratura powszechna na nowym etapie rozwojowym ,posuwa się zbytżółwim krokiem” i nie , «dopełzła» jeszcze do tych pozycji których zajęcia wymaga od niej chwila obecna"62. "Za przestępstwa natury politycznej sądy okręgowe wymierzają zbyt łagodne kary" - pisano w protokole egzekutywy Komitetu Wojewódzkiego PZPR we Wrocławiu. W Wałbrzychu na 60 spraw, wytoczonych za działalność na szkodę gospodarki społecznej i państwowej wydano 50 uniewinniających wyroków. Poszczególne sądy grodzkie masowo zawieszają kary (Nowa Sól $-72 \%$, Wałbrzych - 80\%, Głogów - 66\%), częste są fakty niewłaściwego klasowo orzecznictwa"63. Dla przykładu wskazano Sąd Okręgowy w Kłodzku, który „skazał na karę więzienia robotnika, który pobił żonę za to, że zdjęła ze ściany i podarła portret tow. Stalina. Dopiero na skutek zdecydowanej interwencji K[omitetu] P[owiatowego] sąd ponownie rozpatrzył sprawę, uniewinniając robotnika" ${ }^{4}$. Wskazywano przy tym na strukturę wojskowego aparatu sądowo-prokuratorskiego, która zdaniem nowych władz jest bardziej dostosowana do potrzeb nowego państwa i jest bardziej nowoczesna i postępowa niż w sądownictwie powszechnym ${ }^{65}$.

Ostro skrytykował czteroletni okres działalności Ministerstwa Sprawiedliwości, tj. lata 1944-1948, Stefan Kurowski ${ }^{66}$, Pierwszy Prokurator Najwyższego Trybunału Narodowego, który w tajnej notatce sporządzonej w 1948 r. na polecenie najwyższych czynników partyjnych pisał: „Ministerstwo nie spełniło swych zasadniczych zadań w zakresie wymiaru sprawiedliwości, walkę z przestępczością musiało przejąc sądownictwo wojskowe i Komisja Specjalna". Autor podkreślił, iż „mimo postępującej normalizacji stosunków we wszystkich dziedzinach życia naszego państwa, Ministerstwo nie jest w stanie zlikwidować wytworzonego stanu rzeczy, niedopuszczalnego w warunkach normalnych, i poddać obywateli kompetencji sądownictwa powszechnego (sądów zwykłych, a nie wojskowych)”. Konkludował, że „Ministerstwo nie sprostało swym zadaniom w dziedzinie polityki personalnej, nie spełniło ich częściowo

62 A. Rypiński, Odmłodzić aparat sądowo-prokuratorski, ,Demokratyczny Przegląd Prawniczy", 1948, nr 12, s. 29.

63 AAN, I/208, Kolekcja akt różnej prowieniencji, k. 321.

64 Ibidem.

65 M. Muszkat, O reformę sądownictwa, „Demokratyczny Przegląd Prawniczy”, 1945, nr 2, s. 27.

66 Stefan Kurowski był inspiratorem i autorem licznych ustaw, m.in. ustawy o utworzeniu Komisji Specjalnej do Walki z Nadużyciami i Szkodnictwem Gospodarczym, ustawy o amnestii, ustawy o Najwyższym Trybunale Narodowym, ustawy o odpowiedzialności zaklęskę wrześniowa i faszyzację życia państwowego, ustawy o powołaniu Głównej Komisji Badania Zbrodni Niemieckich w Polsce. AAN, KC PZPR, Centralna Kartoteka, 237/XXIII-149, Akta osobowe Stefana Kurowskiego. 
i w dziedzinie ustawodawstwa”. Wnioskował, iż „,resort Sprawiedliwości pozostaje wciąż jeszcze w życiu nowej Polski niejako resortem «cudzym»"67.

Jednocześnie zaproponował władzom partyjnym następujące rozwiązania ${ }^{68}$ :

- stworzenie specjalnej komórki w KC, której poddane zostanie Ministerstwo Sprawiedliwości; komórka miałaby odpowiadać za funkcjonowanie resortu oraz stworzenie i utrzymanie ścisłego kontaktu pomiędzy kierownictwem ministerstwa a partią,

- radykalne odnowienie obsady kierownictwa ministerstwa ${ }^{69}$,

- obsadzenie kluczowych stanowisk w powszechnym wymiarze sprawiedliwości przez ideowych i politycznie pewnych ludzi z PPR i PPS ${ }^{70}$,

- zmobilizowanie sędziowskich sił rekrutujących się z PPR i PPS i stworzenie z nich wydziałów w sądach okręgowych i sądach apelacyjnych, a następnie Izby w Sądzie Najwyższym (około 150-180 sędziów), którym zostaną poddane sprawy o przestępstwa gospodarcze, a następnie o przestępstwa szczególnie niebezpieczne w okresie odbudowy państwa, w ten sposób nastąpi stopniowe przejście od kompetencji sądów wojskowych do sądownictwa powszechnego,

- przystąpienie do zorganizowania wyodrębnionej prokuratury na wzór sowiecki i szwajcarski,

- w okresie przejściowym - aż do chwili całkowitego opanowania sądownictwa - dla walki z przestępczością i sabotażem gospodarczym utrzymać Komisję Specjalną,

- aż do chwili stworzenia i opanowania nowych kadr nie przeprowadzać reorganizacji sądownictwa i zasadniczych reform $\mathrm{w}$ zakresie prawa materialnego i procesowego,

- dalsza rozbudowa zawodowego szkolnictwa prawniczego,

- zmiana stosunku do pracowników resortu i polepszenie warunków ich pracy.

To rozbicie kompetencji organów wymiaru sprawiedliwości nie zostało jednak zlikwidowane w 1948 r. Proces ten rozłożono na wiele etapów zależnych nie tylko od sytuacji wewnętrznej, ale i od przygotowania nowych

67 AAN, KC, PZPR, 295/VII/162, Tajna notatka Pierwszego Prokuratora Najwyższego Trybunału Narodowego do Komitetu Centralnego Polskiej Partii Robotniczej, k. 31.

68 Ibidem, k.31-32.

69 Pierwszy Prokurator Najwyższego Trybunału Narodowego zdawał jednak sobie sprawę, że całkowita wymiana kadry w powszechnym wymiarze sprawiedliwości była niemożliwa do zrealizowania, proponował zatem zatrudnienie w Ministerstwie Sprawiedliwości podsekretarza stanu z PPR, w którym minister Henryk Świątkowski znalazłby silne oparcie ideowe i polityczne, a który potrafiłby stworzyć przeciwagę dla absolutnej władzy, jaką w ministerstwie posiadał podsekretarz stanu Leon Chajn.

70 Chodzi tu przede wszystkim o nadzór prokuratorski, nadzór sądowy, dyrektorów departamentów, biuro personalne, stanowiska prokuratorów apelacyjnych i okręgowych, prezesów sądów apelacyjnych i okręgowych. 
kadr sądowo-prokuratorskich. Pierwszym etapem tego procesu były reformy z $1949 \mathrm{r}^{71}$ dotyczące przede wszystkim sądownictwa karnego.

Obok ujednolicenia procedury karnej jednym z najczęściej wskazywanych rozwiązań ustrojowych było wyodrębnienie prokuratury z systemu sądownictwa. W dokumentach politycznych, a także w wypowiedziach prasowych, podnoszona była kwestia radykalnej zmiany prokuratury w systemie organów państwowych. Za tym rozwiązaniem opowiadali się politycy, przedstawiciele PPR, a także niektórzy przedstawiciele nauki prawa ${ }^{72}$. Należy pamiętać, że prokuratura w drugiej Rzeczypospolitej ${ }^{73}$ była organizacyjnie związana $\mathrm{z}$ sądami. Powiązanie z sądami znajdowało wyraz w tym, iż ustrój sądów i prokuratury normowany był tym samym aktem prawnym, a jednostki organizacyjne prokuratury funkcjonowały przy sądach okręgowych i apelacyjnych, zaś odrębna prokuratura przy Sądzie Najwyższym. Najwyższym zwierzchnikiem zarówno sądów, jak i prokuratury do 1950 r. był Minister Sprawiedliwości, pełniący jednocześnie stanowisko Naczelnego Prokuratora. Zadaniem prokuratury było stanie na straży praw (co oznaczało wówczas ściganie przestępstw z wyłączeniem śledztw, które prowadzili sędziowie śledczy) i oskarżanie przed sądami. Tylko wyjątkowo prokuratorzy mogli brać udział w postępowaniu cywilnym w sprawach o unieważnienie małżeństwa i ubezwłasnowolnienie.

Zwolennicy odrębności prokuratury wskazywali na takie zadania prokuratury, jak:

- współpraca prokuratury w odbudowie gospodarczej państwa, odbudowie moralnej społeczeństwa, realizacji planu trzyletniego,

- energiczna walka z przestępczością, dostosowana do obecnej rzeczywistości,

- ochrona państwa i społecznego ustroju Rzeczypospolitej Polskiej oraz pogłębienie i umocnienie praworządności demokratycznej ${ }^{74}$.

Zakładano, że jeżeli te zadania zostaną spełnione, powstanie bezpośrednia możliwość przejęcia przez organy prokuratury powszechnej tych dziedzin „dochodźczych i ścigania przestępczości, które dotychczas należą do spe-

71 Cztery ustawy z 27 kwietnia 1949 r. dotyczyły przede wszystkim sądownictwa karnego: o zmianie prawa o ustroju sądów powszechnych (Dz. U. Nr 32, poz. 238), o zmianie przepisów postępowania karnego (Dz. U. Nr 32, poz. 238), o zmianie dekretu o postępowaniudoraźnym (Dz. U. $\mathrm{Nr} 32$, poz. 239), o zmianie niektórych przepisów kodeksu postępowania cywilnego, prawa upadtościowego oraz przepisów wprowadzających matżeńskie prawo majątkowe (Dz. U. Nr 32, poz. 239). Ustawa z dnia 27 kwietnia 1949 r. zniosła także instytucję sędziego śledczego, a jego uprawnienia przekazano prokuratorowi.

72 M. Rychter, O reformę wymiaru sprawiedliwości, „Demokratyczny Przegląd Prawniczy”, 1947, nr 8.

${ }^{73} \mathrm{Na}$ temat prokuratury II RP zob. M. Materniak-Pawłowska, Podstawy prawne ustroju prokuratury w Polsce w latach 1918-1928, „Czasopismo Prawno-Historyczne”, 2014, t. 64, z. 2, s. 109-132, tam też dostępna literatura.

74 AAN, PG, 34/132, Kronika prokuratury PRL, k. 52. 
cjalnychorganów przejściowych"75. Krytyczną ocenę tych postulatów formułowali przedstawiciele Polskiego Stronnictwa Ludowego (PSL) ${ }^{76}$. Jednak wkrótce część posłów PSL aresztowano, a wśród nich osoby wypowiadające się w kwestiach związanych z wymiarem sprawiedliwości ${ }^{77}$.

Reformy dotyczące prokuratury w latach 1944-1950 polegały na:

- stworzeniu możliwości powiązania działalności prokuratury z innymi organami państwowymi,

- rozszerzeniu uprawnień prokuratury w postępowaniu karnym poprzez zniesienie instytucji sędziego śledczego, w następstwie czego skupiały one w swoich rękach całość postępowania przygotowawczego oraz uzyskały uprawnienia stosowania środków zapobiegawczych (głównie aresztu tymczasowego),

- udzielenie prokuratorowi uprawnień do umarzania postępowania karnego w wypadku znikomej szkodliwości społecznej czynu przestępczego,

- udzielenie prokuratorowi uprawnień do wnoszenia rewizji nadzwyczajnych,

- formułowanie obowiązku wierności prokuratorów wobec ustroju i władzy ludowej obok istniejącego już obowiązku bezstronności.

Ustawą z 20 lipca 1950 r. o Prokuraturze Rzeczypospolitej Polskiej ${ }^{78}$ prokuratura została oddzielona od sądów i wyodrębniona jako samodzielny pion organów państwowych, niezależny od administracji centralnej i terenowej oraz podległy jedynie najwyższym organom władzy, tj. Radzie Państwa i pośrednio Sejmowi. Nastąpiło wprowadzenie tak zwanego „leninowskiego modelu prokuratury". Utworzono urząd Prokuratora Generalnego i Generalną Prokuraturę, prokuratury wojewódzkie i powiatowe. Wprowadzono funkcję określaną jako tzw. nadzór ogólny. Całość postępowania przygotowawczego podporządkowano prokuratorowi. Poza ramami prokuratury pozostawał jednak nadal pion prokuratury wojskowej, na czele której stał Naczelny Prokurator Wojskowy. Obie prokuratury (powszechną i wojskową) łączyła tylko osoba Naczelnego Prokuratora Wojskowego, który był jednym z zastępców Prokuratora Generalnego. Połączenia prokuratury powszechnej z prokuratu-

75 Ibidem.

76 „Gazeta Ludowa” nr 29 z 3 grudnia 1945 r.

77 F. Wójcickiego i W. Bryję zatrzymano w czasie przekraczania granicy i postawiono zarzut z art. 88 kkWP, F. Roch-Kowalskiego oskarżono z art. 3 dekretu z 22 stycznia 1946 r. o odpowiedzialności za klęskę wrześniowa i faszyzację kraju, A. Kowalskiego z art. 7 dekretu o przestępstwach szczególnie niebezpiecznych w okresie odbudowy Państwa (mkk), K. Nadobnika, T. Nowaka z art. 5 mkk; S. Bańczyk, T. Kołakowski i S. Wójcik opuścili kraj.

${ }^{78}$ W 1950 r. uchwalono kolejnych pięć ustaw: o Prokuraturze Rzeczypospolitej Polskiej (Dz. U. Nr 38, poz. 346), o zmianie prawa o ustroju sąów powszechnych (Dz. U. Nr 38, poz. 347), o zmianie przepisów postępowania karnego (Dz. U. Nr 38, poz. 348), o zmianie przepisów postępowania w sprawach cywilnych (Dz. U. Nr 38, poz. 349), o zmianie dekretu z dnia 16 listopada 1945 r.o utworzeniu i zakresie działania Komisji Specjalnej do Walki z Nadużyciami i Szkodnictwem Gospodarczym (Dz. U. Nr 38, poz. 350). 
rą wojskową w jednolitą i niepodzielną Prokuraturę Polskiej Rzeczypospolitej Ludowej (pozostawiając jej jednostki organizacyjne) dokonała ustawa z 14 kwietnia 1967 r. $^{79}$

Powołanie w 1950 r. prokuratury jako odrębnego i niezależnego od rządu organu państwowego nastąpiło poprzez mechaniczne przeniesienie wzorów sowieckich i miało na celu uczynienie z prokuratury zasłony dla łamania praworządności przez organy bezpieczeństwa.

IV. Przy tworzeniu - zaraz po zakończeniu drugiej wojny światowej, a nawet jeszcze w czasie jej trwania - polskich organów wymiaru sprawiedliwości na pierwsze miejsce wysunął się problem właściwej obsady stanowisk sędziowskich i prokuratorskich. Nie było to łatwe zadanie, ponieważ najeźdźca, zarówno niemiecki, jak i sowiecki, niszcząc inteligencję polską, wymordował wielu prawników i urzędników sądowych ${ }^{80}$. Sprawę komplikował ponadto fakt, że komuniści, obejmując władzę w Polsce, nie posiadali dostatecznej liczby wykształconych prawników ideologicznie związanych z nową władzą. W tej sytuacji zaistniała konieczność chociażby czasowego zatrudnienia w powszechnym wymiarze sprawiedliwości przedwojennej kadry sądowoprokuratorskiej. W latach 1944-1950 stanowiła ona zdecydowaną większość zatrudnionych. Niektórzy z zatrudnionych należeli do kategorii wybitnych. Swój autorytet zawodowy zawdzięczali zdolnościom prawniczym, wszechstronnemu wykształceniu, nieskazitelnemu i stanowczemu charakterowi oraz wysokiej kulturze osobistej. Prawnicy ci potrafili zachować zawodową uczciwość nawet w tak trudnych czasach. Rzecz jasna, że kadrze takiej nie chciano powierzyć prowadzenia spraw o przestępstwa polityczne ${ }^{81}$. A wytyczne partii komunistycznej dotyczące sądzenia były jasne: karać twardą ręką! Instrukcje udzielane prezesom sądów, a za ich pośrednictwem wszystkim sędziom przez najwyższe instancje partyjne były czytelne: ten, kto nie będzie postępował zgodnie z wytycznymi, pożegna się z awansem, zostanie przeniesiony do innego wydziału lub będzie zmuszony do rozstania się z pracą. Albo będzie dyspozycyjny, albo go nie będzie. Domagano się, aby sądy były, w myśl reguł ukutych przez Lenina - ,transmisją Partii do mas”, w tym wypadku mas prawniczych. Ci, którzy nie podporządkowali się dyrektywom władz, byli traktowani jako ,element klasowo obcy” i usuwani. Potwierdza to w swoich wspomnieniach Wacław Barcikowski, w latach 1945-1956 Pierwszy Prezes Sądu Najwyższego: „Ministerstwo zwalczało zaciekle sędziów przedwojennych. Rozumowano dość schematycznie, bez głębszego rozeznania, że są wstecznikami, i nie mają kredytu politycznego, przyklejano im etykietkę anty-

79 Dz. U. 1967, Nr 13, poz. 55.

80 Zob. S. Kalbarczyk, Polscy pracownicy nauki - ofiary zbrodni sowieckich w latach II wojny światowej, Warszawa 2001.

81 H. Cieśluk, 1944 - notatki lubelskie, „Problemy Praworządności”, 1974, nr 7, s. 43-47. 
semitów"82. Dlatego też w badanym okresie większość spraw o przestępstwa polityczne została wyłączona spod kompetencji sądownictwa powszechnego i przekazana sądom wojskowym.

Należy również pamiętać, że z jednej strony byli sędziowie, prokuratorzy, adwokaci nieustraszeni, nieugięci i konsekwentni w działaniu, którzy wykorzystując swoje bogate doświadczenie zawodowe starali się (na ile było to możliwe) złagodzić ostrze stalinowskiego prawa karnego, ale z drugiej strony byli i tacy, którzy czy to w nadziei uzyskania awansu, czy ze strachu, z przekonania i wiary w zwycięstwo represji byli gotowi poddać się ogólnej sugestii, wyczuć sytuację i surowo karać.

Nie oznacza to bynajmniej, że problem obsady kadrowej w powszechnym wymiarze sprawiedliwości pozostał na uboczu głównych zainteresowań komunistów. Nic podobnego. Wyjęcie spod kompetencji sądownictwa powszechnego pewnych kategorii spraw od samego początku traktowane było jako stan tymczasowy i przejściowy. Programowe założenia ujednolicenia wymiaru sprawiedliwości wymagały odpowiedniej polityki personalnej. Jej wyrazem stała się dążność nie tylko do uzupełniania kadry sędziowsko-prokuratorskiej, ale do zastąpienia jej ludźmi, którzy byliby gwarancją „,właściwego rozumienia przez nich zadań władzy ludowej”. Tym bardziej, że wytyczne władz polityczno-partyjnych kładły największy nacisk na skuteczność działania aparatu ochrony prawnej, przy ogólnie tolerancyjnym stosunku do konieczności przestrzegania norm prawnych ${ }^{83}$.

Należy pamiętać, że w badanym okresie liczba sankcji w postaci kary śmierci była przerażająca. Olbrzymia była również liczba przestępstw, gdzie kara zaczynała się od pięciu lat więzienia ${ }^{84}$. Można w tym miejscu przypomnieć sprawę urzędnika pocztowego, którego główną pasją była hodowla gołębi. Urzędnik, na swoje nieszczęście, napisał do organu Związku Zawodowego Pocztowców entuzjastyczny artykuł sławiący jakieś przemówienie Sta-

82 W. Barcikowski, W kręgu prawa i polityki. Wspomnienia z lat 1919-1956, Katowice 1988, s. 158.

83 Wskazywano, że „(...) organizacja sądownictwa oparta została o stare kadry sędziowskoprokuratorskie”, które nie współpracują z „władzami bezpieczeństwa publicznego i sądownictwem wojskowym”, co w konsekwencji, zdaniem władz, doprowadziło do „katastrofalnego orzecznictwa” AIPN BU, 01222/2848/ D, k. 45-46. Podkreślano, że w ,takim kształcie sądownictwo powszechne nie jest przygotowane do rozpoznawania przestępstw istotnych dla przebudowy nowego ustroju oraz że nie posiada zaufania obecnych władz" Konferencja Ministra Sprawiedliwości, Warszawa, 16-17 XI 1946 r., referat J. Ordyńca, „Wojskowy Przegląd Prawniczy”, 1946, nr 4.

${ }^{84} \mathrm{~W}$ badanym okresie odbyło się szereg procesów politycznych, w których rozprawy oparto na sfałszowanej dokumentacji dowodowej. Aresztowania i śledztwa kończyły się zwykle surowymi odstraszającymi wyrokami, podawanymi selektywnie do wiadomości publicznej, orzeczono przez sądy (lub składy) wojskowe 5641 kar śmierci, w tym 2838 wyroków, tj. 50,3\% wykonano. Dane za: K. Szwagrzyk, Prawnicy czasu bezprawia. Sędziowie i prokuratorzy wojskowi w Polsce 1944-1956, Kraków-Wrocław 2005, s. 86. W tym samym okresie na najwyższy wymiar kary sądy powszechne skazały od 2148 do 2244 osób. Księga świadectw. Skazani na karę śmierci w czasach stalinowskich i ich losy, red. K. Madeja J. Żaryn i J. Żurek, Warszawa 2005, s. XXXVI. 
lina. Zakończył ten artykuł słowami ,gołębiarze wszystkich krajów łączcie się" 85 . Urzędnikowi wytoczono sprawę o wyszydzanie i otrzymał karę pięciu lat więzienia ${ }^{86}$. W innej sprawie chłop oskarżony o zabicie krowy (i to własnej!) otrzymał karę siedmiu lat więzienia ${ }^{87}$. Do wymierzania tak surowych kar potrzebne były nie tylko odpowiednie przepisy, ale i również specjalni sędziowie-politrucy.

Dlatego też 22 stycznia 1946 r. komuniści uchwalili dekret o wyjątkowym dopuszczeniu do obejmowania stanowisk sędziowskich, prokuratorskich, notarialnych oraz do wpisania na listę adwokatów ${ }^{88}$, który zwalniał kandydata na prokuratora $\mathrm{z}$ obowiązku posiadania wykształcenia prawniczego; w rzeczywistości jednak kandydaci na prokuratora lub sędziego często nie mieli żadnego wykształcenia lub legitymowali się wykształceniem w zakresie szkoły zawodowej. „Przyjęcie zasady, że sędzia musi mieć wyższe wykształcenie prawnicze jest oczywiście słuszne" - mówił kilka lat później, w 1957 r., podsekretarz stanu w Ministerstwie Sprawiedliwości, Tadeusz Rek (odpowiedzialny za reformę adwokatury), ale jednocześnie podkreślał, że ,postawienie tego wymogu wszystkim sędziom, absolwentom szkół prawniczych, byłoby nie liczeniem się ze stanem faktycznym". Zdaniem wiceministra ci, których stać na odbycie wyższych studiów prawniczych, ,powinni je ukończyć”, ci zaś, którzy nie są w stanie zdobyć wyższego wykształcenia, a chcą pracować w wymiarze sprawiedliwości, ,powinni być zwolnieni z tego obowiązku, jeśli wykonują swoje obowiązki sędziowskie w stopniu dostatecznym"89.

Cytowany dekret dał podstawę prawną do tworzenia dla potrzeb wymiaru sprawiedliwości średnich szkół prawniczych o skróconym programie i przyśpieszonym cyklu szkolenia ${ }^{90}$. Ponadto resort sprawiedliwości zdecydował

85 AAN, PG, 951, Protokół Wojewódzkiego Zjazdu Prawników Województwa Katowickiego w dniu 9 grudnia 1956 r. w Katowicach, s. 137.

86 Ibidem.

87 Ibidem, k. 138.

88 Dz. U. 1946, Nr 4, poz. 33.

89 AAN Ministerstwo Sprawiedliwości (MS), 1/213, Protokoły posiedzeń Kolegium Ministerstwa Sprawiedliwości, k. 50.

907 kwietnia 1946 r. w Łodzi odbyło się uroczyste otwarcie pierwszej Szkoły Prawniczej Ministerstwa Sprawiedliwości, połączone z inauguracją pierwszego kursu przeszkoleniowego dla kandydatów do prokuratury. W uroczystości wzięli udział m.in. wiceprezydent KRN i pierwszy prezes SN Wacław Barcikowski, pierwszy prokurator SN Zdzisław Piernikowski, minister Poczt i Telegrafów Józef Putek i inni. Kurs obliczony został na 120-150 osób. Program kursu przewidziany na 6 miesięcy, obejmował trzy grupy przedmiotów: 1. przedmioty ogólne (ustrój państwa, ogólne zasady prawa, zasady wykładni prawa, ustrój sądów i prokuratury), 2. przedmioty kryminologiczne (prawo karne materialne i procesowe, sądownictwo i postępowanie specjalne, kryminologia, polityka kryminalna), 3. przedmioty pomocnicze (prawo cywilne, procedura cywilna). Szkoła prawnicza w Łodzi istniała do kwietnia 1952 r. i przeprowadziła 6 kursów, które ukończyło ok. 320 absolwentów. P. Kładoczny, Ksztatcenie prawników w Polsce w latach 1944-1989, „Studia Juridica", 1998, t. XXXV, s. 97. 15 czerwca 1947 r. utworzono szkołę prawniczą we Wrocławiu. Otwarcie szkoły prawniczej we Wrocławiu, „Demokratyczny Przegląd Prawniczy”, 1947, nr 7 
się na uruchomienie pierwszego eksperymentalnego kursu sędziowskiego. Wspomnieć należy, że w latach 1948-1954 powstały dwie szkoły: Centralna Szkoła Prawnicza im. Teodora Duracza ${ }^{91}$ i Wyższa Szkoła Prawnicza im. Teodora Duracza ${ }^{92}$.

W listopadzie 1952 r. Wiceminister Sprawiedliwości Henryk Cieśluk na polecenie Wydziału Administracyjnego KC PZPR dokonał analizy obsady kadrowej w resorcie sprawiedliwości. Z jego informacji wynika, że w latach 1945-1952 wszystkie wydziały prawa uniwersytetów w Polsce wykształciły 7943 absolwentów, z tego do pracy w prokuraturze przyjęto 821 osób, do sądownictwa 98793. Natomiast w latach 1946-1952 średnie szkoły prawnicze i Wyższa Szkoła Prawnicza im. Teodora Duracza wykształciły 1353 absolwentów. Do pracy w sądownictwie i prokuraturze zostało skierowanych 907 absolwentów średnich szkół prawniczych, z tego w prokuraturze zostało zatrudnionych 589 osób $^{94}$, pozostali trafili do sądów.

Absolwenci średnich szkół prawniczych początkowo zatrudniani byli w prokuraturze. Jedną z takich osób był prokurator Władysław Dymant, w latach 1950-1956 wicedyrektor Departamentu Specjalnego Generalnej Prokuratury. Prokurator Dymant legitymował się wykształceniem zawodowym. Od

s. 45, „Demokratyczny Przegląd Prawniczy”, 1948, nr 1, s. 57-58; Egzaminy w szkole prawniczej we Wroclawiu, „Demokratyczny Przeglad Prawniczy”, 1948, nr 2, s. 57; Postowie Sejmu Ustawodawczego w Szkole Prawniczej we Wrocławiu, „Demokratyczny Przegląd Prawniczy”, 1948, nr 3, s. 59; Akcja szkoleniowa, „Demokratyczny Przegląd Prawniczy”, 1949, nr 5, s. 63; Zakończenie kursu w szkole prawniczej we Wroctawiu, „Demokratyczny Przegląd Prawniczy”, 1950, nr 8-9, s. 103. Szkoła w Gdańsku-Jelitkowie powstała pod koniec 1947 r. i istniała do września 1948 r. P. Kładoczny, Kształcenie prawników..., s. 97. Szkoła w Toruniu powstała 3 kwietnia 1948 r., Szkoła w Szczecinie istniała od czerwca 1950 r. do sierpnia 1951 r., w tym samym roku utworzono szkołę o specjalności prokuratorskiej w Zabrzu, która istniała do lipca 1951 r. Ibidem, s. 98.

${ }_{91}$ Centralna Szkoła im. Teodora Duracza powstała 1 czerwca 1948 r. na mocy zarządzenia Ministra Sprawiedliwości z 14 maja 1948 r. i istniała do 19 czerwca 1950 r. Zob. A. Lityński, O prawie i sadach..., s. 143; P. Kładoczny, Kształcenie prawników..., s. 100-102; Z.A. Ziemba, Prawo przeciwko spoleczeństwu ..., s. 380; Zarządzenie Ministra Sprawiedliwości z 14 maja 1948 r. o otwarciu Centralnej Szkoly Prawniczej im. Teodora Duracza w Warszawie, „Dziennik Urzędowy Ministerstwa Sprawiedliwości” 1948 (br nr pozycji). Zob. także M. Zaborski, Szkolenie sędziów 'nowego typu'w Polsce Ludowej, część I: Średnie Szkoty prawnicze, „Palestra”, 1998, nr 1-2, s. 79-92; część II: Centralna Szkoła Prawnicza im. Teodora Duracza i Wyższa Szkoła Prawnicza im. Teodora Duracza, „Palestra”, 1998, nr 3-4, s. 105-110; część III: Oficerska Szkoła Prawnicza, „Palestra”, 1998, nr 5-6, s. 131-141; część IV: Fakultet Wojskowo-Prawniczy, „Palestra”, 1998, nr 7-8, s. 99-105.

92 Wyższa Szkoła Prawnicza im. Teodora Duracza powstała na podstawie rozporządzenia Rady Ministrów z 1 kwietnia 1950 r. Dz. U. 1950, Nr 13, poz. 126. Na mocy rozporządzenia Ministra Sprawiedliwości z 18 lipca 1950 r. utworzono w Wyższej Szkole Prawniczej studium zaoczne (Dz. U. 1950, Nr 30, poz. 278). Pierwszeństwo w przyjęciu mieli absolwenci średnich szkół prawniczych zatrudnieni na stanowiskach sędziowskich i prokuratorskich. Szkołę zlikwidowano 21 sierpnia 1951 r. Dz. U. 1951, Nr 47, poz. 347.

${ }^{93}$ AAN, MS, Notatka dla Wydziału Administracyjnego KC PZPR w sprawie obsady kadrowej w resorcie Ministerstwa Sprawiedliwości, sędziów, asesorów, aplikantów na dzień 1 XI 1952 r., k. 4 .

94 Ibidem, k. 6. 
1946 r. był członkiem partii komunistycznej, sekretarzem Podstawowej Organizacji Partyjnej w Generalnej Prokuraturze. W latach 1948-1949 „studiował” w Szkole Prawniczej we Wrocławiu i na tej podstawie został powołany do służby w komunistycznym aparacie wymiaru sprawiedliwości. W jego aktach osobowych zapisano, że „(...) wykazał zdolności organizacyjne, trafność w podejmowaniu decyzji i nawiązał właściwą współpracę z organami bezpieczeństwa" ${ }^{95}$.

„Instynkt klasowy” posiadał „sędzia” Marian Tomzik ${ }^{96}$. Urodził się 4 czerwca 1906 r. w Częstochowie w rodzinie robotniczej. Ukończył cztery klasy szkoły powszechnej i jeden rok kursu mechanicznego. Po śmierci ojca w 1919 r., mając zaledwie trzynaście lat, musiał zarabiać na utrzymanie rodziny. Pracował jako robotnik w Hucie Częstochowa. Rozpoczął też aktywnie działać w ruchu komunistycznym. W 1926 r. wstąpił do Komunistycznej Partii Polski. We wrześniu 1930 r. został - jak zresztą wielu przedwojennych polskich komunistów - aresztowany i osadzony w więzieniu w Częstochowie, następnie w Piotrkowie. Po miesięcznym śledztwie został zwolniony, co zapewne pasowało go już na działacza partyjnego. Był członkiem PPR, następnie PZPR. Aparatczyk partyjny średniego szczebla. Od 19 czerwca 1946 r. był sekretarzem Komitetu Dzielnicowego przy Hucie Częstochowa. W tym samym czasie powierzono mu pełnienie funkcji przewodniczącego Komisji Specjalnej do walki z nadużyciami i szkodnictwem gospodarczym w Łodzi. Kolejny awans otrzymał 24 lipca 1950 r., kiedy został dyrektorem Biura Wykonawczego Komisji Specjalnej w Warszawie. Tak był opiniowany przez przełożonych: „Tow. Tomzik, wysunięty robotnik i b. KPP-owiec, jest doświadczonym działaczem partyjnym i pracownikiem Komisji Specjalnej. Uważany jest obecnie za najlepszego przewodniczącego Wojewódzkiej Delegatury Komisji Specjalnej. Posiada on śmiałość decyzji, znajomość terenu i środowisk, dobry poziom pracy zawodowej" ${ }^{97}$. W latach 1948-1949 był członkiem egzekutywy KW PZPR w Kielcach. 26 stycznia 1953 r. Wydział Administracyjny KC PZPR rekomendował go na stanowisko wiceprezesa Sądu Najwyższego. W opinii służbowej zapisano, że „Tow. Tomzik pracuje w Biurze Wykonawczym Komisji Specjalnej od 1950 r. i na tej robocie poważnie wyrósł"98. Jak wynika z akt „sędziego" Tomzika, nie musiał on znać przepisów prawa, wystarczyła bowiem znajomość zadań, jakie partia komunistyczna postawiła w tym okresie przed wymiarem sprawiedliwości. Tomzik był odpowiedzialny za najbardziej represyjne przedsięwzięcia w Sądzie Najwyższym.

95 AAN, KC PZPR, Centralna Kartoteka,XX/26447, Akta osobowe Władysława Dymanta.

96 Ibidem, XXX/3924, Akta osobowe Mariana Tomzika.

${ }_{97}$ Ibidem, Wniosek o zatwierdzenie kandydata na stanowisko dyrektora Biura Wykonawczego Komisji Specjalnej.

98 Ibidem, k. 28 i 29. 
Złowrogą rolę odegrał niewątpliwie przedwojenny komunista Stefan Kalinowski, w latach 1946-1950 dyrektor Biura Wykonawczego Komisji Specjalnej w Warszawie, przyszły Generalny Prokurator PRL. Urodził się 2 września 1907 r. w Warszawie. Do 1939 r. pracownik tramwajów miejskich w Warszawie. Od 1923 r. członek, a od 1935 r. aktywny działacz związkowy z ramienia KPP. W latach 1935-1938 był przewodniczącym Komisji Kulturalno-Oświatowej Związku Zawodowego Pracowników Użyteczności Publicznej w Warszawie. W okresie wojny przebywał na terenie Związku Sowieckiego w Stalińsku, gdzie przez kilka dni pełnił funkcję sędziego ludowego. W 1943 r. wstąpił do 1 Dywizji Piechoty im. Tadeusza Kościuszki. Brał udział w bitwie pod Lenino. Po „wyzwoleniu” jako zastępca kierownika Wydziału Zawodowego KC PPR w Lublinie organizował związki zawodowe. Od 1946 r. pracował w Komisji Specjalnej w Warszawie, pełniąc funkcję dyrektora Biura Komisji ${ }^{99}$. W tym okresie brał udział w przygotowaniu reformy wymiaru sprawiedliwości. W uznaniu zasług dla komunistów w 1950 r. otrzymał nominację na stanowisko Generalnego Prokuratora PRL ${ }^{100}$. Już 18 grudnia 1950 r. wydał tajne zarządzenie, które zobowiązywało prokuratorów do wydawania postanowień o aresztowaniu na okres do dwóch miesięcy osób podejrzanych, na żądanie organów bezpieczeństwa, bez przedstawienia materiałów śledztwa ${ }^{101}$. Kalinowski był „twórcą systemu pracy, który doprowadził do łamania praworządności przez Departament IV Specjalny Prokuratury Generalnej”. Potwierdził to prokurator Kazimierz Kukawka 22 marca 1957 r. przed Komisją badającą działalność prokuratora Kalinowskiego w okresie łamania przez niego prawa: ,W 1953 r. zgłosił się do tow. Kalinowskiego Fejgin i okazał mu materiały dotyczące śmierci Dobrzyńskiego (4 lata od chwili śmierci). Tow. Kalinowski zwołał wówczas naradę, w której brali udział: Podlaski, Borys i Tomzik i zastanawiali się nad tym, jak zachować w tajemnicy sprawę zejścia śmiertelnego Dobrzyńskiego. Żadnych wniosków wówczas wobec winnych nie wyciągnięto, mimo, że wiedziano, iż Fejgin przez 2 lata uzyskiwał sankcje prokuratorskie na nieboszczyka (przestępstwo z art. 287 k.k.), a Kędziora spowodował śmierć Dobrzyńskiego (art. 230 § 2 k.k.)"102. Ponadto Departament IV Generalnej Prokuratury bez zastrzeżeń akceptował szereg niezgodnych z procedurą i bezprawnych działań organów bezpieczeństwa.

Sądownicy-,,demokraci” liczne dowody swojej lojalności składali również i w latach późniejszych.

${ }_{99}$ AAN, PG, 34/132, Kronika Prokuratury PRL, k. 29.

100 AAN, KC PZPR, VI/6, Protokół nr 23 posiedzenia Sekretariatu Biura Organizacyjnego w dniu 24 lipca 1950 r., k. 73.

101 AAN, PG, 958, Zarządzenie nr 23/50 z 18 grudnia 1950 r., k. 7; Sprawozdanie Komisji powołanej dla zbadania przejawów tamania praworzadności przez pracowników Generalnej Prokuratury i Prokuratury m. st. Warszawy, ,Zeszyty Historyczne”, 1984, z. 67, s. 78.

102 Ibidem, 958, Akta sprawy przeciwko prokuratorowi Stefanowi Kalinowskiemu, k. 2. 
Podsumowując można stwierdzić, że reaktywowanie przez komunistów po drugiej wojnie światowej powszechnego wymiaru sprawiedliwości opartego na rozwiązaniach organizacyjnych wypracowanych w Drugiej Rzeczypospolitej oraz na przedwojennej kadrze sądowo-prokuratorskiej było procesem tymczasowym. Jednocześnie tworzono instytucje nowe, całkowicie podporządkowane nowej władzy, takie jak: specjalne sądy karne, sądy obywatelskie czy wydziały karne w sądach powszechnych orzekające w składach ławniczych, do których stopniowo wprowadzano ludzi oddanych partii komunistycznej.W ten sposób ograniczano władztwo sądów powszechnych. Prawników wychowanych i wykształconych w Drugiej Rzeczypospolitej, a zdaniem władz politycznie niedostosowanych do nowej rzeczywistości politycznej, usuwano z powszechnego wymiaru sprawiedliwości ${ }^{103}$.

\section{BIBLIOGRAFIA}

\section{1. Źródla}

\section{Źródła archiwalne}

Archiwum Akt Nowych; zespoły: Prokuratura Generalna, Komitet Centralny Polskiej Zjednoczonej Partii Robotniczej, Ministerstwo Sprawiedliwości.

Instytut Pamięci Narodowej Biuro Udostępniania i Archiwizacji Dokumentów; akta kontrolne śledztwa, akta osobowe (nomenklatura), akta osobowe (funkcjonariusze).

\section{Dokumenty i wydawnictwa źródłowe}

Komisja Specjalna do Walki z Nadużyciami i Szkodnictwem Gospodarczym 1945-1954. Wybór dokumentów, wstęp i oprac. D. Jarosz i T. Wolsza, Warszawa 1995.

Protokoty z posiedzeń Biura Politycznego KC PPR 1944-1945, oprac. A. Kochański, Warszawa 1995.

Sprawozdanie Komisji powołanej dla zbadania przejawów łamania praworząności przez pracowników Generalnej Prokuratury i Prokuratury m. st. Warszawy, „Zeszyty Historyczne" 1984.

103 W latach 1949-1951 w stan spoczynku przeniesiono około 800 osób. Dane za: A. Machnikowska, Prawne i faktyczne uwarunkowania pracy sędziów sądów powszechnych w latach 19441946, w: System represji stalinowskich $w$ Polsce 1944-1956. Represje w Marynarce Wojennej, Gdańsk 2003, s. 68. Jak wynika z dokumentów źródłowych w sądach w 1953 r. planowano zwolnienie z różnych przyczyn 80 osób i wymianę 200 osób. W 1954 r. - zwolnienie 80, wymianę 250, w 1955 r. - zwolnienie 80, wymianę 350, w 1956 r. - zwolnienie 80, wymianę 240 osób. W prokuraturze planowano wymianą objąć w 1953 r. około 20 osób, w 1954 r. 130, w 1955 r. 170, a w 1956 r. 60 osób. Do tej liczby należy dodać jeszcze około 80 zwolnień rocznie będących następstwem próśb o zwolnienie, chorób, śmierci oraz zwolnień przez komisje dyscyplinarne. AAN, MS, Notatka o sytuacji kadrowej w sądownictwie i prokuraturze, 338, k. 32-37. 


\section{Literatura}

Auscaler G., Wolter W., Prawo karne, [w:] Dziesięciolecie prawa Polski Ludowej 1944-1954. Zbiór studiów, red. L. Kurowski, Warszawa 1955.

Barcikowski W., W kręgu prawa i polityki. Wspomnienia z lat 1919-1956, Katowice 1988.

Bartoszewski W., Pod prą. Moje środowisko niepokorne 1945-55. Wspomnienia dziennikarza i więźnia, oprac. M. Komar, Warszawa 2011.

Cieśluk H., 1944-notatki lubelskie, „Problemy Praworządności”, 1974, nr 7.

Cyprian T., Sawicki J., Siedem wyroków Najwyższego Trybunału Narodowego, Poznań 1962.

Fiedorczyk P., Komisja Specjalna do Walki z Nadużyciami i Szkodnictwem Gospodarczym. Studium historycznoprawne, Białystok 2002.

Fieldorf M., Zachuta L., Generat „,Nil” August Emil Fieldorf. Fakty, dokumenty, relacje, Warszawa 1993.

Fieldorf M., Zachuta L., Więzienie i proces generała „Nila”, „Tygodnik Powszechny" nr 10 z 5 marca 1989 r.

Gumkowski J., Kułakowski T., Zbrodniarze hitlerowscy przed Najwyższym Trybunatem Narodowym, Warszawa 1961.

Jakubowski G., Sadownictwo powszechne w Polsce w latach 1944-1950, Warszawa 2002.

Jankiewicz S., Przygotowania rzadu RP w latach II wojny światowej do procesu zbrodniarzy wojennych. Dekret prezydenta Rzeczypospolitej o odpowiedzialności karnej za zbrodnie wojenne, „Pamięć i Sprawiedliwość”, Warszawa 1997, t. 40.

Kładoczny A., Prawo jako narzędzie represji w Polsce Ludowej (1944-1956), Warszawa 2004.

Kładoczny P., Kształcenie prawników w Polsce w latach 1944-1989, „Studia Juridica", 1998, t. XXXV.

Księga świadectw. Skazani na karę śmierci w czasach stalinowskich $i$ ich losy, red. K. Madej, J. Żaryn, J. Żurek, Warszawa 2005.

Lityński A., Historia prawa Polski Ludowej, wyd. 5, Warszawa 2013.

Machcewicz A., Kazimierz Moczarski. Biografia, Kraków 2009.

Machnikowska A., Prawne i faktyczne uwarunkowania pracy sędziów sąów powszechnych w latach 1944-1946, [w:] System represji stalinowskich w Polsce 1944-1956. Represje w Marynarce Wojennej, Gdańsk 2003.

Marat S., Snopkiewicz J., Zbrodnia. Sprawa generała Fieldorfa-Nila, Warszawa 1989.

Muraszko G., Noskowa A., Sowietskije prisudstwie w Wostocznoj Jewropie 1944-48, [w:] Awtoritarnyje reżymy w Centralnoj i Wostocznoj Jewropie, Moskwa 1999.

Musiał F., Polityka czy sprawiedliwość? Wojskowy Sąd Rejonowy w Krakowie (1946-1955), Kraków 2005.

Muszkat M., O reformę sądownictwa, „Demokratyczny Przegląd Prawniczy”, 1945, nr 2.

Muszkat M., Jeden czy dwa systemy prawne?, „Przegląd Notarialny”, 1949, z. 7-8.

Materniak-Pawłowska M., Podstawy prawne ustroju prokuratury $w$ Polsce $w$ latach 1918-1928, „Czasopismo Prawno-Historyczne”, 2014, t. 64, z. 2. 
Ptaszyński R., Wojskowy Sad Rejonowy i Wojskowa Prokuratura Rejonowa w Szczecinie w latach 1946-1955, Szczecin 2010.

Romanowska E., Karzące ramię sprawiedliwości ludowej. Prokuratury wojskowe w Polsce w latach 1944-1955, Warszawa 2012.

Romanowska E., Sylwetka bohatera Polski Podziemnej Porucznika Aleksandra Kielasińskiego, [w:] Różnymi drogami do niepodległości. Studia z historii najnowszej, red. M. Żuławnik, B. Świtalska, Warszawa 2014.

Rybicki M., Ławnicy ludowi w sadach PRL, Warszawa 1968.

Rypiński A., Odmłodzić aparat sądowo-prokuratorski, „Demokratyczny Przegląd Prawniczy", 1948, nr 12.

Rzepliński A., Sąownictwo w PRL, Warszawa 1990.

Sawicki J., O prawie sądów specjalnych, [w:] Wymiar sprawiedliwości w odrodzonej Polsce, Warszawa 1945.

Sawicki J., Walawski W., Zmiana istoty prawa czy stosunku do prawa. Rzecz o praworzadności, „Wojskowy Przegląd Prawniczy”, 1945, z. 2,

Skrzypek A., Mechanizmy uzależnienia. Stosunki polsko-radzieckie 1944-1957, Pułtusk 2002.

Steinsberowa A., Widziane z ławy obrończej, Paryż 1977.

Stawarska-Rippel A., Prawo sadowe Polski Ludowej 1944-1950 a prawo Drugiej Rzeczypospolitej, Katowice 2006.

Szopa P., W imieniu Rzeczypospolitej... Wymiar sprawiedliwości Polskiego Państwa Podziemnego na terenie Podokręgu AK Rzeszów, Rzeszów 2014.

Szwagrzyk K., Prawnicy czasu bezprawia. Sędziowie i prokuratorzy wojskowi w Polsce 1944-1956, Kraków-Wrocław 2005.

Świątkowki H., Siedlecki W., Merz E., Udział ludu w wymiarze sprawiedliwości, Warszawa 1954.

Torańska T., Oni, Warszawa 1997.

Walczak R., Polityka, sądy, prokuratura, Warszawa 1990.

Wasilewski J., Sprawa generała Augusta Emila Fieldorfa, „Palestra”, 1989, nr 11-12.

Waltoś S., Sędzia śledczy - rys historyczny, [w:] Nowy model postępowania przygotowawczego - sędzia śledczy, Warszawa 2010.

Wnuk R.,Lubelski Okręg AK DSZ i WiN 1944-1947, Warszawa 2000.

Wojciechowska J., Zdrada ojczyzny w polskim prawie karnym na tle porównawczym, Wrocław-Warszawa-Kraków-Gdańsk 1975.

Zaborski M., Szkolenie sędziów 'nowego typu'w Polsce Ludowej, część I: Średnie szkoły prawnicze, „Palestra”, 1998, nr 1-2, część II: Centralna Szkoła Prawnicza im. Teodora Duracza i Wyższa Szkoła Prawnicza im. Teodora Duracza, „Palestra”, 1998, nr 3-4, część III: Oficerska Szkoła Prawnicza, „Palestra”, 1998, nr 5-6, część IV: Fakultet Wojskowo-Prawniczy, „Palestra”, 1998, nr 7-8.

Zalewski S., Dwa Kryzysy. Reforma sądownictwa karnego, „Głos Sądownictwa”, 1932, $\mathrm{nr} 1$.

Ziemba Z. A., Prawo przeciwko spoleczeństwu. Polskie prawo karne w latach 1944-1956, Warszawa 1997.

Żelazko J., „Ludowa sprawiedliwość”. Skazani przez Wojskowy Sąd Rejonowy w Łodzi (1946-1955), Łódź 2007. 


\section{TRANSFORMATIONS IN THE GENERAL ADMINISTRATION OF JUSTICE IN POLAND BETWEEN 1944 AND 1956}

\section{Summary}

After the war, the prewar organization of general jurisdiction was restored. It was based on the bill of the President of the Republic of Poland called The law on common courts (consolidated text, Journal of Laws from 1932. No. 102, item 863) from the 6th of February 1928 which was in force. Prewar lawyers were recruited to serve in the jurisdiction system. This legal status was maintained until 1950. In reality however, changes in the justice system occurred since the beginning of the Polish People's Republic. New kinds of special courts were created. They included special criminal courts and departments of general courts adjudicating in juries. A new organ was created which was called The Special Commission for Combating Economic Fraud and Wrecking which was devoid of the characteristics of judicial procedures. People's courts were created. New people, who were devoted to the communist party, were introduced to these institutions. They set up people's courts. Lawyers educated in prewar Poland who were not suited to the new political reality, according to the authorities, were removed from the general administration of justice.

\section{LES TRANSFORMATIONS DANS L'ORGANISATION DE LA JUSTICE EN POLOGNE DANS LES ANNÉES 1944-1956}

\section{Résumé}

Après la guerre, c'était l'organisation juridictionnelle d'avant-guerre basée sur le règlement du Président de la République du 6 février 1928 Loi sur la juridiction de droit commun (texte consolidé, Dz. U. 1932. N. 102, pos. 863), qui a été restituée. Les juristes d'avant-guerre ont été invités au travail dans les services de la juridiction. Un tel système existait jusqu'en 1950. En fait, depuis le début du régime fonctionnant en République populaire de Pologne, des changements dans le système de juridiction de droit commun ont été successivement introduits. Un nouveau type de tribunal appelé spécial a été constitué. Ces institutions comprenaient des tribunaux pénaux spéciaux et des départements des tribunaux du droit commun où des jurés (juges non professionnels) examinaient des affaires et rendaient des jugements. On a créé une nouvelle institution dépourvue des caractéristiques des procédures judiciaires: la Commission spéciale pour la lutte contre la fraude et la destruction économique. Des tribunaux populaires ont été constitués. Ces institutions étaient gérées par un nouveau personnel composé de personnes dévouées au Parti communiste. Des juristes formés et éduqués en Pologne d'avant-guerre ont été expulsés du système de juridiction parce que - selon les autorités - ils ne se sont pas adaptés à la nouvelle réalité politique. 